\title{
Handel miedzią węgierską a restytucja rządów Władysława Łokietka w Polsce (1304-1312)
}

Profesorowi Stawomirowi Gawlasowi w 70. rocznice urodzin

\begin{abstract}
Zarys treści: Autor dowodzi, że walka o kontrolę nad szlakiem handlowym, którym przewożono ze Spiszu do Flandrii węgierską miedź, miała poważny wpływ na okoliczności odzyskania władzy przez Władysława Łokietka w Polsce w latach 1304-1306. Wiele wskazuje na to, że bunt wójta Alberta w Krakowie i jego przebieg były w poważnym stopniu uwarunkowane wydarzeniami na Węgrzech w latach 1311-1312. Głównymi udziałowcami w handlu miedzią byli kupcy westfalscy, z Dortmundu i Soestu, którzy w 1305 r. osiedlili się w Toruniu.
\end{abstract}

Content outline: The author argues that the struggle over controlling the trade route, by which Hungarian copper was transported from Spiš to Flanders, exerted immense influence on the circumstance of regaining power in Poland by Ladislaus the Short in 1304-1306. It seems probable that the mutiny of Vogt Albert in Cracow and its consequences were directly related to the events in Hungary in 1311-1312. The main participants in copper trade were Westphalian merchants from Dortmund and Soest, who settled down in Toruń in 1305.

Słowa kluczowe: handel miedzią węgierską, Flandria, Dortmund, Soest, Lubeka, Gdańsk, Toruń, Kraków, Koszyce, Amadej, Władysław Łokietek, Maria bytomska, bunt wójta Alberta, bitwa pod Rozgony

Keywords: Hungarian copper trade, Flanders, Dortmund, Soest, Lübeck, Gdańsk, Torun, Cracow, Košice, Amadej, Ladislaus the Short, Maria of Bytom, Vogt Albert's mutiny, Battle of Rozgony

\section{WĄTPLIWOŚCI WOKÓŁ RESTYTUCJI WŁADZY PAŃSTWOWEJ PRZEZ WŁADYSŁAWA ŁOKIETKA W POLSCE}

W polskiej historiografii przynajmniej od czasów Oswalda Balzera trwa nieprzerwana dyskusja nad genezą zjednoczenia państwa polskiego na przełomie XIII i XIV w. ${ }^{1} \mathrm{~W}$ wielu pracach omawiano aspekty gospodarcze tego procesu, starano się

${ }^{1}$ O. B a 1 z e r, Królestwo Polskie 1295-1370, t. I-III, Lwów 1919-1920 (wyd. 2: Kraków 2005); J. B a s z k i e w i c z, Powstanie zjednoczonego państwa polskiego na przełomie XIII i XIV wieku, Warszawa 1954; G. L a b u da, Uwagi o zjednoczeniu państwa polskiego na przełomie XIII i XIV wieku, Kwartalnik Historyczny 62, 1955, nr 3, s. 125-149; K. J a s i ń s k i, Z problematyki zjednoczenia państwa polskiego na przełomie XIII i XIV wieku, Zapiski Historyczne 21, 1956, z. 1-2, s. 198-241; S. T r a w k o w s k i, W sprawie powstania zjednoczonego państwa polskiego w XIII i XIV wieku: w związku z książką Jana Baszkiewicza, Powstanie 
zdefiniować przyczyny społeczne, które doprowadziły do zjednoczenia Królestwa Polskiego za panowania dwóch ostatnich Piastów. Kwestiom gospodarczym i społecznym poświęcono wiele miejsca w połowie lat pięćdziesiątych w toku dyskusji wywołanej przez monografię Jana Baszkiewicza. Przywołując niektóre ówczesne tezy, nie można zapominać o ideologii i schematach narzuconych wówczas polskiej historiografii. W tym świetle nie dziwi jedna z głównych tez J. Baszkiewicza, że możni w przeważającej części nie byli zainteresowani zjednoczeniem kraju, w przeciwieństwie do szeregowego rycerstwa i mieszczaństwa. W dyskusji niekiedy szczegółowo ustosunkowywano się do tej tezy; np. Stanisław Trawkowski zarzucał, że J. Baszkiewicz zbytnio przeceniał rolę kształtowania się międzydzielnicowych więzi rynkowych na przełomie XIII i XIV w. S. Trawkowski tak formułował wówczas swoje poglądy: „Patrycjat tych miast [tj. Krakowa i Wrocławia - TJ] zainteresowany był bowiem w danym momencie więcej w rozwoju handlu dalekosiężnego, niż w utwierdzaniu początków więzi między rynkami lokalnymi. Toteż patrycjat wrocławski i krakowski opowiada się za związkiem z Czechami, a nie za połączeniem wszystkich ziem polskich. Jest rzeczą przy tym charakterystyczną, iż bunt Alberta 1311-1312 r. podjęty został po utracie Pomorza Wschodniego przez Łokietka, w momencie trudności politycznych odbudowanego państwa. Gdyby patrycjatowi krakowskiemu zależało na rozwoju więzi rynkowych z innymi dzielnicami, gdyby zwłaszcza odgrywała rolę konkurencja z Toruniem, to Kraków powinien poprzeć Łokietka, powinien dążyć do włączenia Pomorza Gdańskiego z powrotem w obręb państwa. W ten bowiem sposób eliminowałoby się niebezpieczeństwo konkurencji toruńskiej i zabezpieczało się handel na linii Kraków - Gdańsk - Flandria. Tymczasem patrycjat decyduje się na podjęcie buntu, gdyż najważniejszy dla niego jest handel dalekosiężny, idący połączeniami równoleżnikowymi”’2. Zdecydowałem się na przytoczenie tego dość długiego cytatu, gdyż autor przypisuje ważną rolę handlowi dalekosiężnemu w kształtowaniu postaw patrycjatu wielkich miast wobec wydarzeń towarzyszących zjednoczeniu państwa polskiego ${ }^{3}$. Jak zobaczymy niżej, chociaż czynnik ten był niezwykle ważnym elementem, to jednak zarówno S. Trawkowski, jak i pozostali uczeni nie potrafili prawidłowo odczytać oddziaływania handlu dalekosiężnego na ówczesne postawy polityczne.

W dyskusji nad zjednoczeniem państwa polskiego wiele nowego wniosła rozprawa habilitacyjna Janusza Bieniaka ${ }^{4}$. W pracy tej - całkowicie wolnej od schematów towarzyszących wcześniejszej dyskusji - autor ten zidentyfikował rody rycerskie,

zjednoczonego państwa polskiego na przełomie XIII i XIV wieku, Warszawa 1954, Przegląd Historyczny 47, 1956, s. 531-548; ostatnio zob. T. J u r e k, Jana Baszkiewicza Powstanie zjednoczonego państwa polskiego z perspektywy półwiecza, Czasopismo Prawno-Historyczne 57, 2005, z. 1, s. 147-170, a także te n ż e, Polska droga do korony królewskiej 1295-1300-1320, w: Proměna středovýchodní Evropy raného a vrcholného středověku. Mocenské souvislosti a paralely, Brno 2010, s. 139-191.

2 S. Trawk ow sk i, W sprawie, s. 544.

${ }^{3} \mathrm{~W}$ podobnym duchu wypowiedział się H. S a m s on ow i c z, Miasta wobec zjednoczenia Polski w XIII/XIV wieku, w: Ars historica. Prace z dziejów powszechnych i Polski, Poznań 1976, s. 425-436.

${ }^{4}$ J. B i e n i a k, Wielkopolska, Kujawy, ziemie łęczycka i sieradzka wobec problemu zjednoczenia państwowego w latach 1300-1306, Toruń 1969. 
a także elity mieszczańskie, które wsparły Władysława Łokietka w walce o likwidację władztwa Przemyślidów na ziemiach polskich. Autor przedstawił też szereg konkluzji ogólnych; pisał m.in., że ,polityczna rzeczywistość ziem polskich na przełomie XIII i XIV w. przebiegała więc nie tyle w biało-czarnym schemacie walki między zwolennikami a przeciwnikami unifikacji państwa w ogóle, ile pod znakiem rywalizacji różnorodnych kierunków zjednoczeniowych"5. J. Bieniak był zdania, że można mówić np. o programie zjednoczenia państwa polskiego wokół władcy czeskiego ${ }^{6}$. Podkreślił też wagę rywalizacji „Małopolan i Wielkopolan o przewodnictwo w zjednoczonym państwie. W jej toku ukształtowała się bardzo szybko przewaga Małopolan, którzy z reguły wygrywali swe kolejne posunięcia"' . W świetle tych ustaleń rodzi się pytanie, dlaczego Małopolanie uzyskali przewagę nad Wielkopolanami, dlaczego ci drudzy w znacznie mniejszym stopniu wsparli Władysława Łokietka.

Gdy obserwujemy poczynania Władysława Łokietka w latach 1304-1306, a następnie w jeszcze trudniejszych chwilach lat 1308-1312, nasuwa się podstawowe pytanie, jak w ogóle udało się temu księciu wygrać walki w pierwszym okresie, a następnie przetrwać tak poważne ciosy, jakie mu później zadano. W 1304 r. Władysław Łokietek - po kilku latach niebytu - nieoczekiwanie zjawił się na scenie politycznej i ostatecznie rozprawił się z władztwem Przemyślidów na ziemiach polskich. Stało się to wbrew wszelkim przewidywaniom, mimo spadających na niego ciosów. Niewątpliwie na początku pomogły mu dwa zrządzenia losu, a mianowicie śmierć Wacława II (21 VI 1305), a następnie jego syna Wacława III (4 VIII 1306). Nie można jednak zapominać, że gdy Władysław Łokietek rozpoczął w końcu 1304 r. walkę o panowanie w Polsce, król Wacław II - mimo iż powstała w tym czasie przeciwko niemu wielka koalicja z udziałem papiestwa i Habsburgów - był najpotężniejszym władcą w Europie Środkowej, a może nawet w całej Europie. Po jego śmierci pozycja Wacława III była nadal silna, a mimo to - jak dowodzą tego postanowienia rozejmu zawartego 25 I 1306 r. przez prołokietkowych buntowników z królewskim starostą - klęska Czechów na ziemiach polskich, zwłaszcza w Małopolsce, ziemi łęczyckiej i sieradzkiej, na Kujawach i części Wielkopolski, była już tylko kwestią czasu $^{8}$. Ostatecznym przypieczętowaniem zwycięstwa Władysława Łokietka, które nastąpiło już po śmierci Wacława III i niewątpliwie w związku z wiadomością o niej, był wiec elekcyjny duchowieństwa, rycerstwa i mieszczan małopolskich w Krakowie 1 IX 1306 r., który ostatecznie usankcjonował władzę nowego księcia w Małopolsce ${ }^{9}$. Likwidacja władztwa Przemyślidów nie uchroniła Łokietka przed dwoma

5 Tamże, s. 283.

6 Tamże, s. 278.

7 Tamże, s. $290 \mathrm{n}$.

8 Tamże, s. 27 n., por. cały rozdział: „Stan posiadania stron w rozejmie toruńskim (25 I 1306 r.)".

9 Podstawa źródłowa to Rocznik świętokrzyski i Kronika katedralna krakowska oraz dokumenty Łokietka dla biskupa krakowskiego, Krakowa i Nowego Sącza. Pierwszy z roczników przedstawia to następująco: Anno domini 1305 Wenceslaus rex Bohemie et Polonie occisus est in Olomunecz sub fraude, in domo decani, infra meridiem, per quendam familiarem suum de Austria, de consensu principum ac nobilium, quia ista vice voluit habere regnum Ungarie, et habuisset. Sequenti vero anno nobiles Polonie, Cracovie, Syradie convocacione facta et convenientes in unum elegerunt ducem Wladislaum Cuyawye in regem Polonie, et Bohemos 
kataklizmami politycznymi, a mianowicie utratą Pomorza Gdańskiego oraz buntem wójta Alberta w latach 1311-1312. Każde z tych wydarzeń mogło doprowadzić do ponownego upadku władztwa Władysława Łokietka. Jak udało mu się przetrwać ten kryzys i ostatecznie w 1320 r. sięgnąć po koronę Królestwa Polskiego?

Wielokrotnie próbowano odpowiedzieć na te pytania, zwracając uwagę na niezwykłą wytrwałość, waleczność i charyzmę księcia Władysława. Bez tych cech charakteru zapewne nigdy nie udałoby mu się ponownie wskrzesić Królestwa. Musimy jednak pamiętać, że samo podjęcie walki w 1304 r., a później kolejne boje z licznymi wrogami, musiały wiele kosztować. Gdy spadły na Łokietka potężne ciosy i klęski, nawet najbardziej - mówiąc nieco ironicznie - patriotyczne i świadome celów politycznych rycerstwo z pewnością opuściłoby swojego władcę, gdyby nie dysponował dalej odpowiednimi środkami pieniężnymi (lub przynajmniej gwarancjami ich pozyskania). Niekiedy próbowano odpowiedzieć na pytanie, skąd czerpał Władysław Łokietek środki na podjęcie tak kosztownych przedsięwzięć. W wydanej pośmiertnie monografii poświęconej Władysławowi Łokietkowi Edmund Długopolski tak zastanawiał się nad finansowaniem walk księcia polskiego w 1304-1305 r.: „Skąd wziął Łokietek środki pieniężne na tę wyprawę, nie wiemy. Nie było żadnych skarg na Łokietka, że oddział jego żyje z rabunku; widocznie wypłacał swoim towarzyszom żołd. Czy papież dostarczył Łokietkowi pieniędzy na sfinansowanie tej akcji, a jeżeli tak, czy z sum zebranych w Polsce tytułem dziesięciny nałożonej na duchowieństwo przez Bonifacego VIII na pomoc dla Ziemi Świętej - nie wiemy"10. Mimo iż papież należał do koalicji antyczeskiej, to jednak musiałby być bardzo naiwny, aby posyłać pieniądze „,bankrutowi”, który przegrał już wszystko, nie posiadał de facto ani skrawka ziemi, ani żadnego wojska, a swoją małżonkę i najbliższą rodzinę musiał - jak wszystko na to wskazuje - powierzyć jednemu z mieszczan z Radziejowa.

W niniejszym artykule stawiam sobie za cel wyjaśnienie okoliczności, które towarzyszyły powrotowi Władysława Łokietka do Polski pod koniec 1304 r. i które pozwoliły na dość szybkie umocnienie jego władztwa w Małopolsce, ziemiach sieradzkiej i łęczyckiej, Kujawach i na Pomorzu Gdańskim. Tytuł artykułu może stwarzać mylne wrażenie, że chcę dowieść, iż wszelkim panaceum na kłopoty finansowe Władysława Łokietka był rozwijający się wówczas handel miedzią. Byłoby to duże uproszczenie. Będę starał się jednak dowieść, że poznanie tego handlu, a zwłaszcza losów możnowładcy Amadeja, pod którego kontrolą pozostawały tereny, gdzie wydobywano miedź węgierską, pozwalają inaczej spojrzeć na wydarzenia towarzyszące

de Wislicia, de Cracovia, de Sandomiria, de castris, que tenuerunt, forti manu expulerunt, similiter in Polonia, Poznania, Gnezne, et aliis municionibus (Monumenta Poloniae historica, t. III, Lwów 1878, s. 77); drugie źródło natomiast podaje dokładną datę dzienną: prefatus dux Wladislaus sequenti anno in die sancti Egidii a terrigenis, episcopo et civibus unanimiter susceptus, Cravovie et Sandomirie ducatus obtinuit, et successive Syradie et Lancicie, Cuyavie et Polonie terras recuperavit (W. K ę t r z y ń s k i, O rocznikach polskich, Rozprawy Akademii Umiejętności, Wydział Historyczno-Filozoficzny 34, 1896 s. 349). Źródła te dokładnie omówił J. B i e n i a k, Wielkopolska, s. 44 n. Filiacje wymienionych przekazów rocznikarskich były przedmiotem studiów W. D r e 1 i c h a r z a, Annalistyka małopolska XIII-XV wieku. Kierunki rozwoju wielkich roczników kompilowanych, Kraków 2003, s. 207 n. (tamże starsza literatura).

10 E. D ł u g o p o $1 \mathrm{~s} \mathrm{k} \mathrm{i,} \mathrm{Władysław} \mathrm{Łokietek} \mathrm{na} \mathrm{tle} \mathrm{swoich} \mathrm{czasów,} \mathrm{Wrocław} \mathrm{1951,} \mathrm{s.} 57$. 
zarówno sukcesom, jak i klęskom Władysława Łokietka w początkowym okresie jego rządów (1304-1312).

\section{PRZEJECIE WŁADZY W STARYM MIEŚCIE TORUNIU W 1305 R. PRZEZ KUPCÓW Z DORTMUNDU I SOESTU A HANDEL MIEDZIĄ WĘGIERSKĄ}

Handel miedzią węgierską (tj. słowacką), zwaną też w przekazach hanzeatyckich miedzią ,polską”, którą eksportowano głównie do Flandrii, ale także do Anglii i do miast włoskich, które zaopatrywały się w miedź właśnie we Flandrii, był przedmiotem wielu badań i trudno cokolwiek nowego powiedzieć na ten temat, zwłaszcza po publikacji wybitnego słowackiego historyka Ondreja Halagi ${ }^{11}$. Jedna tylko rzecz uszła uwagi badaczy, a mianowicie znaczenie i dochodowość tego handlu. Jak wiadomo, w północnej Europie, od Anglii, czy nawet od Portugalii, największe dochody czerpano z handlu z Rusią, z czterema jej głównymi ośrodkami gospodarczo-handlowymi Nowogrodem Wielkim, Smoleńskiem, Połockiem oraz Kijowem, który jednak po najeździe Mongołów podupadł, a jego rolę w znacznej mierze przejął Włodzimierz Wołyński, mający lepsze połączenia z koloniami kupieckimi nad Morzem Czarnym. Import towarów ruskich (przede wszystkim futer, skórek, drewna, wosku i innych produktów leśnych) oraz eksport towarów zachodnio- i środkowoeuropejskich (głównie sukna flandryjskiego i angielskiego, śledzi oraz wielu towarów luksusowych) stały się podstawą bogactwa wielu miast europejskich jeszcze przed powstaniem Hanzy, której ośrodki były w późnym średniowieczu (XIII-XV w.) głównymi beneficjentami tej wymiany. Nie ulega wątpliwości, iż handel z Rusią był głównym źródłem dochodów miast hanzeatyckich. Nie oznacza to jednak, że był to najbardziej zyskowny handel w tej części Europy. Wiele wskazuje na to, że była w działalności handlowej hanzeatów jedna specjalność, która przynajmniej w tym czasie przynosiła większe zyski. Chodzi właśnie o import miedzi węgierskiej. W czyich rękach głównie spoczywał ten handel i jaka była jego dochodowość, można przekonać się na podstawie mało znanej rozprawy Karl-Ottona Ahnsehla, poświęconej handlowi morskiemu i kupiectwu Starego Miasta Torunia w latach 1362-137012. Wprawdzie był to już okres znacznie późniejszy niż czasy Łokietkowe, ale - jak zobaczymy - ustalenia K.-O. Ahnsehla pozwalają zrozumieć zaskakujące wydarzenia z przełomu XIII i XIV w. Okazuje się, że w latach sześćdziesiątych XIV w. miedź węgierska miała na rynku hanzeatyckim

${ }^{11}$ Nieprześcignioną rozprawą z tego zakresu jest monografia O. H a l a g i, Košice - Balt. Výroba a obchod v styku východoslovenských miest s Pruskom (1275-1526), Košice 1975; por. wcześniejszą pracę t e g o ż, Kaufleute und Handelsgüter der Hanse im Karpatengebiet, Hansische Geschichtsblätter 85, 1967, s. 59-84, a także te g o ż, Počiatky Košíc a zrod metropoly, Košíce 1993. Wiele informacji dotyczących związku wydarzeń w Polsce (głównie w Krakowie) i na Węgrzech (głównie w Koszycach) podaje t e n ż e, Boj Košic proti oligarchii Omodejovcov a Matúš Trenčiansky, Hitorický časopis 34, 1986, nr 3, s. 326-348. Niewiele wnosi rozprawa A. O b a r y - P a w ł o w s k i e j, Polityka gospodarcza Władysława Łokietka, Lublin 2014, s. 311 n., bardzo przydatny pod względem bibliograficznym jest natomiast artykuł t e j że, Polish and Hungarian relations in the Middle Ages (from the second half of the $13^{\text {th }}$ century to the end of the $14^{\text {th }}$ century), w: Hungaro-Polonica. Young Scholars on Medieval Polish-Hungarian Relations, Pécs 2016, s. 225-263.

12 K.-O. A h n s e h 1, Thorns Seehandel und Kaufmannschaft um 1370, Marburg 1961. 
status niemal monopolu; import miedzi ze Szwecji był znacznie niższy, a miedź z Harzu stanowiła margines dostaw do Europy Zachodniej ${ }^{13}$. Jak dowodzą rachunki cła funtowego, patrycjusze toruńscy byli najliczniej reprezentowani wśród kupców hanzeatyckich, którzy handlowali miedzią. Tylko na przełomie 1362 i 1363 r. torunianie przetransportowali na Zachód niemal 267 łasztów miedzi o wartości prawie 22 tys. grzywien pruskich ${ }^{14}$. $\mathrm{Z}$ tego 11,5 tys. grzywien przypada na patrycjuszy zasiadających w radzie miejskiej, w tym zaś 7,4 tys. grzywien na dwie rodziny von Soest i von Allen ${ }^{15}$. Ustalenia te potwierdził później również O. Halaga ${ }^{16}$. Obok miedzi ci sami kupcy toruńscy importowali z Węgier w dużych ilościach także żelazo oraz w niewielkim stopniu ołów. Import miedzi węgierskiej, a w mniejszym stopniu wosku, był głównym źródłem dochodów kupców toruńskich ${ }^{17}$. W tym czasie byli oni najbogatszymi kupcami na ziemiach polskich. Dopiero pod koniec XIV w. zostali przynajmniej pod względem demograficznym - zdystansowani przez gdańszczan.

Wielką zasługą K.-O. Ahnsehla było zbadanie i określenie pochodzenia najbogatszych rodzin patrycjatu toruńskiego w latach sześćdziesiątych XIV w. Jak zaznaczyłem to w niedawno opublikowanym artykule, rezultaty tych badań są zaskakujące: „Alle die hier genannten Thorner Familien werden aus Soest gekommen sein. Wird dieses auf die Gesamtheit der Thorner Kaufmannschaft übertragen, so kann etwa ein Drittel als ehemalige Soester bezeichnet werden"18. A zatem jedna trzecia toruńskich patrycjuszy pochodziła, według tego badacza, z jednego miasta, a mianowicie z Soestu, niezwykle ważnego hanzeatyckiego ośrodka z rejonu Hellwegu w Westfalii. Ale to nie wszystko. Okazuje się, że druga najliczniejsza grupa toruńskich patrycjuszy wywodziła się z Dortmundu, równie ważnego centrum gospodarczo-handlowego Hellwegu $^{19}$. Niestety K.-O. Ahnsehl nie podał procentowego udziału dortmundczyków wśród toruńskich patrycjuszy. Na koniec wykazał natomiast, że bezpośredni udział Lubeki w powstaniu toruńskiego kupiectwa nie był wielki. Oczywiście można by wątpić w te ustalenia, gdyby nie świadectwo pewnej niezwykłej uchwały rady miejskiej Starego Miasta Torunia z 1389 r. Rada postanowiła, że nie powinno się w przyszłości nikomu nadawać prawa miejskiego, bez względu na to, „czy byłby to Westfalczyk, czy też może jeszcze ktoś z jakiegokolwiek innego kraju”, gdyby nie przyniósł on wcześniej odpowiedniego listu dobrego urodzenia z miejsca, gdzie

13 Tamże, s. 51. Zob. niżej w niniejszym artykule tabelkę na s. 114

${ }^{14}$ K.-O. A h n s e h 1, Thorns Seehandel, s. 44.

15 Tamże, s. 46.

${ }^{16}$ O. H a 1 a g a, Košice, s. 168 n. Wcześniej wykazy cła funtowego, na których oparli się K.-O. Ahnsehl i O. Halaga, zostały wydane i zanalizowane przez L. K o c z e g o, Materiały do dziejów handlu hanzy pruskiej z zachodem, Rocznik Gdański 7/8, 1933/1934, s. 275-331.

17 Zyski z handlu miedzią wspomagały dochody z handlu z Włodzimierzem Wołyńskim, skąd sprowadzano wiele towarów; spośród nich największy dochód przynosiły import wosku i skórek. Ważny udział w zyskach miał m.in. eksport sukna, a w tym zwłaszcza flandryjskiego, na Ruś i Węgry. Trzeba też zauważyć, że z Węgier (tj. północnej Słowacji) torunianie importowali też niemałe ilości wosku, skórek etc. Nie wiemy tylko, czy towary te pochodziły z tych samych stron co miedź węgierska, czy też pochodziły z Rusi, zob. O. H a la g a, Kaufleute, s. $59-84$.

18 K.-O. A h n s e h l, Thorns Seehandel, s. 116.

19 Tamże, s. 120. 
mieszka, od miasta czy też innej władzy ${ }^{20}$. Z uchwały tej wynika, że o uzyskanie prawa miejskiego starali się głównie Westfalczycy. Ostatecznie zatem możemy powiedzieć, iż w drugiej połowie XIV w. najbogatszą grupę mieszczan na ziemiach polskich tworzyli patrycjusze Starego Miasta Torunia, którzy pochodzili z Soestu i Dortmundu i którzy swoją pozycję majątkową zawdzięczali przede wszystkim handlowi miedzią węgierską.

Związek powyższych ustaleń z tematyką niniejszego artykułu stanie się oczywisty, gdy odpowiemy na pytanie, kiedy owa grupa mieszczan pojawiła się po raz pierwszy w Starym Mieście Toruniu. Zagadnieniem tym zajmowałem się niedawno w innym miejscu ${ }^{21}$, obecnie zaś, po dokonaniu dodatkowej kwerendy, zwłaszcza w źródłach dortmundzkich, udało mi się pogłębić wcześniejsze ustalenia. Otóż do 1304 r. włącznie toruński patrycjat stanowił pod względem pochodzenia niezwykle jednorodną grupę. Patrycjusze toruńscy do tego czasu wywodzili się przede wszystkim z terenu Śląska, z Halle nad Soławą oraz z miast, przez które przechodziły ważne szlaki handlowe prowadzące do Torunia (Gubin, Poznań i Kowal). Wśród mieszczan śląskich ważną rolę odgrywali ci wywodzący się ze Złotoryi oraz pobliskiej Legnicy, a pod koniec XIII w. niewątpliwie z Wrocławia (np. rodzina Leschhorn) i Nysy. Przybysze ze Złotoryi próbowali początkowo w Toruniu kontynuować swoją dawną działalność, czyli wydobycie złota, o czym świadczy posiadanie przez tę rodzinę de Goltberg Złotorii u ujścia Drwęcy do Wisły. Jeżeli chodzi o mieszczan wywodzących się z Halle nad Soławą, to należy pamiętać, że w tym czasie było ono ważnym ośrodkiem produkcji soli, którą, m.in. przez Gubin i Poznań, wraz z innymi towarami, eksportowano do Torunia. O dominacji mieszczan z Halle nie tylko w Toruniu, ale w całym państwie krzyżackim w Prusach, napisano wiele i nie ma potrzeby rozwijania w tym miejscu tego tematu ${ }^{22}$. Pod względem językowym ówczesna elita torunian tworzyła jednorodną grupę i posługiwała się językiem górnoniemieckim (Mittelhochdeutsch). Wśród mieszkańców Starego Miasta Torunia do 1304 r. nie znajdujemy ani jednego (!) patrycjusza czy mieszczanina, który przynależałby do dolnoniemieckiego

${ }^{20}$ Thorner Denkwürdigkeiten, wyd. A. Voigt, Mitteilungen des Coppernicus Vereins 13, 1904, s. 16: daß man forthin niemandt, er sey ein Westpfälinger oder sonst von was Lands jemandt komme, Burgerrecht soll mehr geben, er bringe vorher satsame Briefe seiner Gebuhrt und wo er gewonet hat, von Stettin [w tym wypadku chodzi o miasta w ogóle (,von Städten"), a nie o Szczecin - TJ] oder anderer Herrschaft. Zob. też informację o tzw. ławach św. Rajnolda kupców z Dortmundu w dworach Artusa w Toruniu i Gdański - G. L u n t o w s k i, G. Hö g e 1, T. S c h il p, N. R e i m a n n, Geschichte der Stadt Dortmund, Dortmund 1994, s. 128: „An den Artushöfen, den Gildenhöfen der Fernkaufleute, in Danzig und Thorn gab es die nach dem Stadtpatron benannten Reinoldibänke der Dortmunder Kaufleute“.

${ }^{21}$ T. J a s i ń s k i, Rola Piastów mazowieckich w handlu hanzeatycko-ruskim na przełomie XIII/XIV w., w: Dziedzictwo książąt mazowieckich, Warszawa 2017, s. 61-89.

${ }^{22}$ Ustalenia te są powtórzeniem moich wcześniejszych spostrzeżeń, pogłębionych o wnioski dotyczące zagadnień związanych z Westfalczykami. Zob. T. J a s i ń s k i, Początki Torunia na tle osadnictwa średniowiecznego, Zapiski Historyczne 46, 1981, z. 4, s. 5-34; t e n ż e, Uwarunkowania lokacji Poznania, w: Civitas Posnaniensis. Studia z dziejów średniowiecznego Poznania, Poznań 2005, s. 163-172; K. Z i e lińs k a-M e 1 k o w s k a, Zagadnienie proweniencji elit mieszczańskich w ziemiach: chełmińskiej, lubawskiej i michałowskiej w XIII i XIV wieku, w: Genealogia. Rola związków rodzinnych i rodowych w życiu publicznym w Polsce średniowiecznej na tle porównawczym, Toruń 1996, s. 284 n. 
(hanzeatyckiego) kręgu kulturowego ${ }^{23}$. I oto nagle w 1305 r. możemy zaobserwować niezwykłą rewolucję - zupełnie nieoczekiwanie pojawiają się, dokładnie w 1305 r., liczni mieszczanie z kręgu dolnoniemieckiego i natychmiast zdobywają władzę w Starym Mieście Toruniu. W 1305 r. możemy odnotować z tego kręgu burmistrza Gotszalka von Soest oraz rajców Zygenanda von Essen, Jana Pape, Bertolda von Kopenhagen, Friczka von Hofe (de Curia) oraz Jana Wenko, a być może też Henryka Rockendorfa ${ }^{24}$. I chociaż określenie pochodzenia tych urzędników na podstawie brzmienia nazwiska jest równie precyzyjne, jak określenie przynależności rodowej rycerstwa na podstawie kryterium imionowego, to nie ulega wątpliwości, iż od 1305 r. możemy mówić o dominacji mieszczan z Soestu i Dortmundu wśród toruńskiego patrycjatu ${ }^{25}$. Aby się o tym przekonać, przyjrzyjmy się rajcom starotoruńskim z lat 1305-1324, czyli w pierwszych dwudziestu latach po pojawieniu się Westfalczyków w Starym Mieście Toruniu. Przeprowadzając tę analizę, musimy pamiętać, że łącznie dysponujemy tylko pięcioma pełnymi i jednym szczątkowym wykazem rajców dla tego okresu (a więc nieco ponad 25\% kompletu danych).

Otóż wśród ,nowych” torunian w latach 1305-1324 na czoło wybijają się rodziny pochodzące z Dortmundu. Aż jedenastu ich przedstawicieli było w tym czasie rajcami $^{26}$. Z Soestu pochodziły trzy lub cztery rodziny radzieckie ${ }^{27}$, przy czym wątpliwość wynika z faktu, iż rodzina von Allen mogła pochodzić zarówno z Soestu, jak

${ }^{23}$ W 1261 r. pojawia się jeden raz rajca Tiderich Colner; obecnie uważa się, że nazwisko to jest pochodzenia zawodowego, a jego rozmieszczenie na terenie Niemiec przeczy dolnoniemieckiemu pochodzeniu, zob. np. Hanßen Colner z Magdeburga z połowy XV w. $-<$ http:// www.namenforschung.net/dfd/woerterbuch/vorschau/?tx_dfd_names\%5Bname $\% 5 \mathrm{D}=597 \& \mathrm{tx}$ dfd_names $\% 5$ Baction $\% 5 \mathrm{D}=$ show\&tx_dfd_names $\% 5$ Bcontroller $\% 5 \mathrm{D}=$ Names\&cHash $=2 \mathrm{c}-$ 6f65a26a887e29d1a27514f1ddc3d4>.

${ }^{24}$ Preußisches Urkundenbuch, t. I, cz. 2, wyd. C. P. Woelky, A. Seraphin, Königsberg 1909, nr 840. Zob. R. C z a j a, Urzędnicy miejscy Torunia. Spisy, cz. I, Toruń 1999, s. 38 n.

${ }^{25}$ R. C z a j a, tamże, przyp. 18, zauważa, że wyliczeni przez niego burmistrz i rajcy zostali ,wymienieni jako świadkowie (bez podania funkcji) na dokumencie z 29 IX $1305 \mathrm{r}$. wystawionym przez radę", ale przyjmuje jednak, że to burmistrz i rajcy - jak kiedyś sądził już A. S e m r a u, Katalog der Geschlechter der Schöffenbank und des Ratsstuhls in der Altstadt Thorn 1233-1602, Mitteilungen des Coppernicus-Vereins für Wissenschaft und Kunst zu Thorn 46, 1938, s. 92 („An erster Stelle, also vermutlich Bürgermeister”). Wystawcy nie powinni właściwie być jednocześnie świadkami własnego dokumentu, ale jego charakter, a mianowicie darowizna jednego z mieszczan toruńskich na rzecz rady (w tym na radzieckie convivia), przemawia za takim rozwiązaniem. Jaki bowiem autorytet miejski mógł poświadczać darowiznę na rzecz rajców? Z tego właśnie względu nie wymieniono imiennie rajców na początku dokumentu (jak najczęściej to bywało), a wpisano ich u dołu jako świadków.

${ }^{26}$ Ustalenia na podstawie: K.-O. A h n s e h 1, Thorns Seehandel, oraz Dortmunder Urkundenbuch, wyd. K. Rübel, t. I-II, Dortmund 1881-1910: Johannes Pape rajca 1305 i 1307, burmistrz 1308, ok. 1312 i 1320; Bertoldus de Copenhauen rajca 1305; Meineco Monetarius rajca 1307, 1308, 1312, 1320 i 1324; Zygenandus de Essen rajca 1305; Fricze vom Hofe rajca 1305; Hermann de Essen rajca 1307; Thidemanus Miles rajca 1308, ok. 1312, 1320 i 1324; Ditmar von der Kemenate rajca 1312 i 1320; Konrad de Essen rajca ok. 1312; Henneco Niger rajca 1320; zapewne też Arnoldus Crispus (Crispin?) rajca 1320.

${ }^{27}$ Gotschalk von Soest burmistrz 1305; Johannes Wenko rajca 1305, 1307 i 1308, sędzia ok. 1312; Tideman Rebber rajca 1307; Hermann von Allen (ale być może z Lubeki?) rajca 1320 i 1324. 
i z Lubeki. We wspomnianym artykule przytoczyłem zapomnianą zapiskę wyliczającą kilkunastu kupców toruńskich, pokrzywdzonych przez Bolesława II mazowieckiego ${ }^{28}$. Jak starałem się wykazać, pochodzi ona z końca panowania tego księcia (zm. 20 IV 1313 r.). Wśród owych kilkunastu kupców odnajdujemy czterech, których nazwiska wskazują na pochodzenie z interesujących nas miast westfalskich: dwaj z Soestu (de Tilia oraz Ribber) i także dwaj z Dortmundu (de Curia / vom Hofe oraz Kaminata). Liczyć się trzeba co prawda, że nie wszyscy ze zidentyfikowanych przez nas patrycjuszy rzeczywiście pochodzili z Dortmundu i Soestu. Rodziny o tym samym nazwisku osiedlały się nierzadko w innych miastach hanzeatyckich, będących kolejnymi stacjami na dalekosiężnych szlakach handlowych. Ponieważ jednak badania te opierają się na stosunkowo dużej liczbie nazwisk, więc nie ma wątpliwości co do generalnej tezy, że najpóźniej w 1305 r. w Starym Mieście Toruniu pojawiła się nagle zwarta grupa kupców z Dortmundu i Soestu, która jeszcze w tym roku przejęła władzę w mieście i utrzymała ją przez następne dekady, a głównym źródłem ich bogactwa był handel węgierską miedzią, przywożoną bezpośrednio z Koszyc lub pośrednio z Krakowa.

W związku z tym faktem nasuwają się dwa pytania: dlaczego kupcy Dortmundu i Soestu działali razem oraz dlaczego zjawili się w Starym Mieście Toruniu w 1305 r. lub nieco wcześniej? Na pierwsze pytanie bardzo łatwo odpowiedzieć. Te dwa miasta należały do najważniejszych ośrodków hanzeatyckich. Wraz z całym regionem Hellwegu były rezerwuarem gospodarczym i demograficznym Hanzy. To kupcy Soestu założyli Lubekę w połowie XII w. Później Soest i Dortmund odgrywały najważniejszą po Lubece rolę w handlu z Rusią, o czym świadczy ich nieprzerwana obecność w Nowogrodzie Wielkim, Pskowie i Smoleńsku, a także w Visby na Gotlandii. Obydwa miasta kilkakrotnie zawierały między sobą konfederacje pro pacis conservacione, ostatni raz - licząc do momentu pojawienia się w Starym Mieście Toruniu - w $1303 \mathrm{r}^{29}$ To ostatnie porozumienie zawarte było na cztery lata, do 21 X 1307 r. Gdy zatem mieszczanie obydwu miast zjawili się w Starym Mieście Toruniu ok. 1305 r., ich miasta złączone były związkiem konfederacji. Na marginesie należy zauważyć, że imigracja patrycjuszy z Dortmundu i Soestu do Starego Miasta Torunia na początku XIV w. nie była pierwszą falą imigracyjną Westfalczyków do miast pruskich. Wiemy, iż już w latach osiemdziesiątych XIII w. wielu patrycjuszy elbląskich pochodziło z Westfalii ${ }^{30}$. Na początku XIV w. Westfalczycy dotarli też

${ }^{28}$ Urkundenfunde, wyd. M. Perlbach, Altpreussische Monatsschrift 11, 1874, s. 497-498. Maleńki fragment tego dokumentu został opublikowany też w: Preußisches Urkundenbuch, t. I/2, nr 753, oraz Pommerellisches Urkundenbuch, wyd. Perlbach, Danzig 1882 (dalej cyt.: PllUB), nr 593.

29 Początek dokumentu brzmi następująco: Nos scabini, consules et universitates Tremoniensis et Sisaciensis civitatum notum facimus et protestamur, quod, cum frequenter hostium insultus pateremur, ut eo melius possemus nos in juribus et libertatibus nostris conservare et injuriatorum malitiis, prout expedit, obviare, pro communi commodo et maxime pro pacis conservacione de novo confederacionem ineuntes a festo Undecim milium virginum quod est anno Domini 1303 ad quatuor annos continuos duraturam concordavimus in articulos subsequentes (Hansisches Urkundenbuch, wyd. K. Höhlnbaum, t. II, Halle 1879, nr 41; Dortmunder Urkundenbuch, t. I, nr 293).

${ }^{30} \mathrm{R}$. C z a j a, Udział wielkich miast pruskich w handlu hanzeatyckim, cz. 2, Zapiski Historyczne 60, 1995, z. 4, s. 45, przyp. 12. 
do Krakowa. W 1302 r. w krakowskich źródłach pojawił się przedstawiciel słynnej patrycjuszowskiej rodziny z Dortmundu - Henryk de Sudermann, który zasiadał w radzie krakowskiej i w 1311/1312 r. wziął udział w buncie wójta Alberta ${ }^{31}$. Mieszczanie z Krakowa byli też rajcami w Dortmundzie ${ }^{32}$.

Znacznie trudniej odpowiedzieć na drugie pytanie. Gremialne przybycie Westfalczyków do Starego Miasta Torunia w 1305 r. lub nieco wcześniej ${ }^{33}$ nie mogło się zdarzyć bez zgody i wiedzy Zakonu Krzyżackiego. Należy pamiętać, że Toruń był miastem nadgranicznym, położonym w strategicznym miejscu. Przez miasto biegła najważniejsza dla Zakonu Krzyżackiego droga, łącząca Prusy z krajami Rzeszy, z których pochodziła zdecydowana większość braci zakonnych; chodzi mianowicie o Górną Saksonię, Turyngię i Frankonię ${ }^{34}$. Pojawienie się Westfalczyków krótko przed 1305 r. w Starym Mieście Toruniu musiało być poprzedzone rozmowami z przedstawicielami Zakonu. Aby wyjaśnić okoliczności przybycia kupców z Soestu i Dortmundu do Torunia w tym czasie, musimy się przyjrzeć stosunkom handlowym w okresie poprzedzającym ich pojawienie się.

\section{SYTUACJA NA SZLAKU HANDLOWYM KRAKÓW-GDAŃSK PRZED POJAWIENIEM SIĘ WESTFALCZYKÓW W STARYM MIEŚCIE TORUNIU W 1305 R.}

Miedź węgierska ze Spisza, wydobywana w bliższym i dalszym sąsiedztwie Koszyc, różnymi drogami docierała na drugą stronę Karpat, do Małopolski, która od 1291 r. pozostawała w rękach króla czeskiego Wacława II. Najważniejszymi ośrodkami tranzytu miedzi węgierskiej do Europy Zachodniej w tej części władztwa Wacława II były Podoliniec, Nowy Sącz, a przede wszystkim Kraków. Brak źródeł nie pozwala nam poznać zaangażowania władcy czeskiego we wspieranie handlu tranzytowego miedzią węgierską. Pośrednio o takim wsparciu świadczy jednak fakt, że podczas jednego z pierwszych pobytów w Małopolsce Wacław II nadał w $1292 \mathrm{r}$. prawo składu Podolińcowi ${ }^{35}$ i lokował w tym samym roku Nowy Sącz. Najważniejsze znaczenie miał jednak Kraków, który utrzymał tę pozycję do późnego średniowiecza. Pochodzące z XV w. przysłowie hanzeatów głosiło: „Krakau ist ein Kupferhaus, Visby ein Pech- und Teerhaus, Reval ein Wachs- und Flachshaus, Rostock ein Malzhaus, Danzig ein Kornhaus, Stettin ein Fischhaus, Halberstadt ein Frauenhaus, Hamburg

${ }^{31}$ Najstarsze księgi i rachunki miasta Krakowa od r. 1300 do 1400, wyd. F. Piekosiński, J. Szujski, Kraków 1878, s. 3, 24. Zob. też G. L u n t ow s k i, Kleine Geschichte des Rates der Stadt Dortmund, Dortmund 1970, s. 20.

${ }^{32}$ Dortmunder Urkundenbuch, t. I, nr 110, 123, 125 itd.

33 Ponieważ przedstawiciele Dortmundu i Soestu objęli urzędy miejskie w Starym Mieście Toruniu w 1305 r., więc musieli przybyć do tego miasta najpóźniej przed świętem Petri ad cathedram (22 lutego) tego roku, którego to dnia corocznie wybierano rajców i burmistrza Starego Miasta Torunia. Zapewne więc Westfalczycy przybyli do Torunia już w 1304 r., a być może jeszcze wcześniej. Wiele wskazuje na to, jak zobaczymy niżej, że zjawili się w Toruniu nieprzypadkowo w tym samym czasie (w 1304 r.), co Władysław Łokietek w Małopolsce.

${ }^{34}$ M. D o r n a, Bracia zakonu krzyżackiego w Prusach w latach 1228-1305. Studium prozopograficzne, Poznań 2004, s. 43 n.

${ }^{35}$ O. H a $\mathrm{l}$ a g a, Košice, s. 70-72. 
ein Brauhaus, Lübeck ein Kaufhaus, Braunschweig ein Zeughaus, Magdeburg ein Backhaus, Köln ein Weinhaus und Lüneburg ein Salzhaus" ${ }^{36}$.

Chociaż krakowianie, jak zobaczymy niżej, odbywali bezpośrednie wyprawy kupieckie ze swoimi towarami aż do Flandrii, to jednak nie oni, ani też Westfalczycy, ale lubeczanie odgrywali wówczas główną rolę w handlu na szlaku Gdańsk-Kraków. Kupcy lubeccy działali z terenu Gdańska, a ich największym protektorem na ziemiach polskich w drugiej połowie lat dziewięćdziesiątych XIII w. był Władysław Łokietek. Współpraca pomiędzy księciem a Lubeką była wielokrotnie omawiana w literaturze ${ }^{37}$. Gdy przyglądamy się dokumentom Łokietka dla lubeczan, to przede wszystkim zwraca uwagę ich niezwykły pośpiech i wielkie zainteresowanie uzyskaniem przywilejów handlowych na ziemiach podległych władztwu tego księcia. Już 28 XII 1295 r. w Gnieźnie książę ten objął mieszczan lubeckich omnimodam securitatem per dominia nostra transeundi, ipsos in nostram tuthelam et securitatem recipientes, mandantes universis per districtum dominii nostri constitutis, ut prefatos cives seu eorum nuncios cum curribus transeuntes, nullis molestiis perturbare presumant $^{38}$. Znamienne, że nie ma w dokumencie dla Lubeki mowy o żegludze ani prawie brzegowym, jest natomiast wzmianka o transporcie wozami. Być może nie jest to przypadek. W nieco późniejszych czasach krakowianie zakazywali innym kupcom, a dowodnie kupcom z Koszyc, transportu statkami Wisłą, który rezerwowali wyłącznie dla siebie. Niewykluczone, że ten zwyczaj sięgał czasów panowania Wacława II w Małopolsce i kupcy lubeccy, importując miedź z Krakowa, musieli zadowolić się transportem drogowym. Fakt ten tłumaczyłby pominięcie wszelkich spraw związanych z żeglugą w dokumencie Łokietka, przez którego księstwa i ziemie biegł miedziany szlak handlowy z Krakowa do Torunia i dalej do Gdańska. Na przełomie sierpnia i września 1298 r. lubeczanom udało się uzyskać dwa nowe dokumenty od księcia Władysława Łokietka; w pierwszym, krótszym, książę wziął pod swoją opiekę kupców lubeckich i zwolnił od cła ich wszelkie dobra sive sint in curribus vel vyhiculis, per terram transeuntia, et si eciam per mare Wislam et omnes alias rypas vel fluvios navigare videantur, in civitate Gedanensy, per totam terram Pomoranie et per omnes terminos terrarum nostrarum ${ }^{39}$. W drugim, dłuższym

${ }^{36}$ U. Z i e g l e r, Die Hanse: Aufstieg, Blütezeit und Niedergang der ersten europäischen Wirtschaftsgemeinschaft. Eine Kulturgeschichte von Handel und Wandel zwischen 13. und 17. Jahrhundert, Bern-München-Wien-Scherz 1996, s. 282.

${ }^{37} \mathrm{O}$ roli lubeczan w handlu wiślanym, w tym w Gdańsku, zob. W. D łu g o k ę c k i, Hanza a Gdańsk na przełomie XIII i XIV wieku, w: „Rzeź gdańska” z 1308 roku w świetle najnowszych badań, Gdańsk 2009, s. 27-42; H. S a m s o n o w i c z, Die Hanse an der unteren Weichsel im 13. Jahrhundert, Hansiche Geschichtsblätter 106, 1988, s. 5-17; t e n ż e, Lubeczanie a ziemie Polski w XIII w., Acta Universitatis Nicolai Copernici 204, Historia 24, Toruń 1990, s. 144-153; R. C z a j a, Udział wielkich miast pruskich w handlu hanzeatyckim, cz. 1, Zapiski Historyczne 60, 1995, z. 2-3, s. 24 n.

${ }^{38}$ Codex diplomaticus Lubecensis. Lübeckisches Urkundenbuch, 1. Abt.: Urkundenbuch der Stadt Lübeck, t. I, Lübeck 1843, nr 655; Kodeks dyplomatyczny Wielkopolski, t. II, [wyd. I. Zakrzewski], Poznań 1878, nr 758; w datacji podano rok 1296, ale na pewno liczony a Nativitate (M. B i e l i ń s k a, Kancelaria Władysława Łokietka w latach 1296-1299. Ze studiów nad kancelarią wielkopolską, Studia Źródłoznawcze 6, 1961, s. 33-36).

39 PllUB nr 565; Kodeks dyplomatyczny Wielkopolski, t. II, nr 792. 
dokumencie książę zapewnił lubeczanom niemal monopolistyczną pozycję handlową w Gdańsku ${ }^{40}$. Zostali oni zwolnieni z cła w Gdańsku, na Wiśle, na całym Pomorzu i we wszystkich innych ziemiach książęcych. Ponadto Łokietek zobowiązał się, że gdyby lubeckie towary zostały zrabowane przez ludzi z sąsiednich krajów, to będzie osobiście dochodzić praw lubeczan. Zezwolił wreszcie na budowę w mieście kantoru (pallacium), który uzyskał status eksterytorialny pod względem prawnym, a w tym też prawo azylu ${ }^{41}$. Dowiadujemy się, że w kantorze tym lubeczanie będą składować swoje dobra i towary. Dokument ten był rezultatem szerszej ofensywy dyplomatycznej Lubeki, gdyż - jak zwrócił uwagę Henryk Lesiński - zbliżone pod względem formularzowym dokumenty wystawili wówczas kupcom lubeckim również jutlandzki biskup Chrystian z Ribe (15 XI 1298) oraz inflancki mistrz krajowy Gotfryd (6 I 1299) ${ }^{42}$. W 1299 r. Władysław Łokietek zwrócił się o pomoc do Lubeki, co wywołało zaniepokojenie tej ostatniej. W kolejnym dokumencie z 27 VII 1299 r., wystawionym w Brześciu, książę uspokajająco informował, że nie chodziło mu o pomoc w ludziach, a jedynie o przekazanie mu pewnej sumy pieniędzy: De tenore autem littere vobis ultimo misse vester animus commoveri non debet, quia sicut intelleximus, quod littera habeat, quod a vobis auxilium in propriis personis peteremus, nunquam scribi fecimus nec nostre voluntatis talia fuerunt. Sed quidem verum est, quod vobis peticionem tamquam specialibus amicis direximus pro concedenda quadam summa pecunie $e^{43}$.

Pomijamy dalsze szczegóły kontaktów Władysława Łokietka z lubeczanami i z ich posłem, magistrem Bernardem, odsyłając do wyczerpujących badań Henryka Lesińskiego czy ostatnio Wiesława Długokęckiego ${ }^{44}$. Na podstawie wyżej przytoczonych faktów można stwierdzić, iż lubeczanie na przełomie XIII i XIV w. osiągnęli de facto monopolistyczną pozycję na wszystkich międzynarodowych szlakach handlowych w państwie Władysława Łokietka, zwłaszcza w Gdańsku, dokąd docierały szlaki, lądowe i wodne, którymi transportowano miedź z Koszyc (przez Kraków lub Nowy Sącz). O tym, że lubeczanie byli wówczas na tym szlaku zaangażowani w handel miedzią, świadczy jeden z niedatowanych listów handlowych do rajcy lubeckiego Bernarda von Coesfelda (1299-1301 $)^{45}$. Ponieważ został on zasztyletowany na rynku lubeckim w 1301 r., to list ten musi pochodzić najpóźniej z tego roku. Warto się bliżej przyjrzeć treści tego pisma, gdyż każda wzmianka o handlu miedzią na tym szlaku w tym czasie jest na wagę złota. Otóż z listu skierowanego do Bernarda dowiadujemy się, że jego famulus, Gerhard von Coesfelde, posłał do Flandrii 70 centenarios cupri et unum talentum cere. Dalej czytamy, że miedź ta została posłana przez niejakiego

${ }^{40}$ PllUB nr 564; Kodeks dyplomatyczny Wielkopolski, t. II, nr 793. Najpełniej wpływy Lubeki w Gdańsku pod koniec XIII w. omówił H. L e s iń s k i, Początki i rozwój stosunków polsko-hanzeatyckich w XIII w., Przegląd Zachodni 8, 1952, nr 5/6, s. 130-145.

${ }^{41}$ Bliżej o zakresie tego przywileju, a także statusie kantoru zob. E. R o z enkranz, Dzieje kantoru hanzeatyckiego w Gdańsku, Studia i Materiały do Dziejów Wielkopolski i Pomorza 13, 1978, z. 1 (25), s. 151 n.

${ }^{42}$ Urkundenbuch der Stadt Lübeck, t. I, nr 687-688; zob. H. L e s i ń s k i, Początki, s. 140.

${ }^{43}$ PllUB nr 580; Kodeks dyplomatyczny Wielkopolski, t. II, nr 816.

${ }^{44}$ H. L e s iń s k i, Początki, s. 142 n.; W. D $\nmid$ u g o k ę c k i, Hanza, s. 38 n.

${ }^{45}$ Lübeckisches Urkundenbuch, t. III, nr 39, zwł. 39d. Zob. też R. C z a j a, Udział, cz. 1, s. $28 \mathrm{n}$. 
Konrada von Rekelinghusen najpierw do Elbląga, a potem dopiero do Flandrii. Z tekstu wynika, że była ona wspólną własnością wspomnianego Bernarda von Coesfelda oraz niejakiego Sebolda (Segebolda) de Crispin. Tego ostatniego nieoczekiwanie odnajdujemy w niedatowanym liście rady Chełmna do mistrza krajowego Henryka von Plötzkau (1307-1309). Ten ostatni dokument odnalazł Max Perlbach jako karteczkę pergaminową przyklejoną do okładki rękopisu oznaczonego sygnaturą Msc. 1087 (Postilla super Johannem) wśród zbiorów rękopiśmiennych Królewieckiej Biblioteki Państwowej $^{46}$. Z pisma tego wynika, że za zgodą (per consensum) księcia Siemowita (dobrzyńskiego) znany nam już Sigeboto de Crispin, którego syn był mieszczaninem chełmińskim, stracił cztery tysiące skórek i 10 centenarios cupri ${ }^{47}$.

Można przypuszczać, że energiczne starania lubeczan o kontrolę nad handlem międzynarodowym w państwie Władysława Łokietka, a zwłaszcza o monopolistyczną pozycję w Gdańsku, wynikały ze szczególnej roli tego handlu dla Lubeki. Wydaje się, że swoją wyjątkowość handel ten zawdzięczał właśnie importowi miedzi ze Słowacji. Oczywiście to tylko przypuszczenie, ale jest bardzo prawdopodobne, że owo pallacium w Gdańsku było potrzebne kupcom lubeckim głównie do składowania miedzi. Docierała ona tam wozami i statkami z Krakowa czy błyskawicznie się rozwijającego Nowego Sącza, który spławiał ten towar małymi statkami Dunajcem bezpośrednio do Wisły, z ominięciem Krakowa. Najpewniej dopiero w Gdańsku przeładowywano miedź na lubeckie statki pełnomorskie, które bezpośrednio lub pośrednio (o czym niżej) dowoziły ten niezwykle ważny towar do Flandrii. W Bibliotece Narodowej w Paryżu zachował się francuskojęzyczny tekst, pochodzący zdaniem wydawcy z trzeciej tercji XIII w., zawierający spis towarów, które z różnych królestw były dostarczane do Brugii: „Dou royaume de Polane vient or et argent en plate, cire, vairs et gris et coivre"48. Jak widzimy, wśród wielu metali źródło to wymienia także miedź.

Nie wiemy, czy lubeczanom udało się zachować kontrolę nad handlem miedzią, gdy sprzyjający im Władysław Łokietek został wygnany, a władzę nad Pomorzem Gdańskim i wszystkim ziemiami tego księcia przejął w 1300 r. król czeski Wacław ${ }^{49}$. Sojusz Łokietka z lubeczanami mógł zaszkodzić tym ostatnim, gdy Wacław II przejmował Gdańsk; mogło też jednak dojść do porozumienia lubeczan z królem, w jego rękach bowiem znalazły się wszystkie ziemie polskie, przez które przebiegał szlak miedziany, począwszy od Nowego Sącza i Krakowa aż po Gdańsk. Pozycję Wacława II jako władcy kontrolującego tę drogę wzmacniał szczególnie fakt, iż w 1301 r. jego syn Wacław, mimo oporu ze strony papieża Bonifacego VIII, koronowany został na króla Węgier jako Władysław $\mathrm{V}^{50}$. Oznaczało to przejęcie przez

${ }^{46}$ Urkundenfunde, s. 497-498; A. M e n t z e l - R e u t e r s, Arma spiritualia. Bibliotheken, Bücher und Bildung im Deutschen Orden, Wiesbaden 2003 (Beiträge zum Buch- und Bibliothekswesen 47), s. 283 (rękopis ten pierwotnie należał do zbiorów biblioteki kapituły sambijskiej).

47 Urkundenfunde, s. 498.

${ }^{48}$ Hansisches Urkundenbuch, t. III, Halle 1882-1886, s. 419.

49 O rządach czeskich na Pomorzu zob. K. J a s i ń s k i, Gdańsk pod rządami Władysława Łokietka i Wacławów czeskich, w: Historia Gdańska, t. I, Gdańsk 1978, s. 312 n.; B. Ś 1 i w i ń s k i, Pomorze Wschodnie w okresie rządów księcia polskiego Władysława Łokietka w latach 1306-1309, Gdańsk 2003.

50 J. Š u s t a, Soumrak Přemyslovců a jejich dědictví (České dějiny, t. II/1), Praha 1935, 
czeskich Przemyślidów kontroli nad całym szlakiem handlu miedzią od węgierskich Koszyc aż po Gdańsk. Wprawdzie okazało się niebawem, że kontrola nad słowacką częścią szlaku nastręczała wiele trudności, ale któż mógł w 1301 r. przypuszczać, że sytuacja w najbliższym czasie rozwinie się tak niepomyślnie dla Przemyślidów. Ich kontroli nad szlakiem miedzianym nie zagroziła też ekspansja książąt rugijskich, którzy dążyli do opanowania Gdańska. Z pomocą przyszedł wtedy Zakon Krzyżacki, który w 1301 r. roztoczył „opiekę” nad Gdańskiem w imieniu króla. W mieście tym 29 V 1301 r. mistrz pruski Helwig von Goldbach w obecności Guntera von Schwarzburg oraz komtura toruńskiego Konrada Sacka wystawił dokument, w którym Zakon zobowiązywał się m.in. do przestrzegania przywilejów miejskich ${ }^{51}$. $Z$ dokumentu wynika, że Zakon liczył się wówczas z trwałym przejęciem miasta, wszelkie prawa mieszkańców (m.in. rycerzy, mieszczan, rybaków) były przedmiotem licznych narad. Wszystko jednak potoczyło się nie po myśli Krzyżaków i najpóźniej przed końcem lata 1302 r. musieli oni opuścić Gdańsk.

\section{WALKI O TRON WEGIERSKI DO 1306 R. A SYTUACJA POLITYCZNA NA ZIEMIACH POLSKICH NA POCZĄTKU XIV W.}

Sytuacja na Węgrzech skomplikowała się po śmierci ostatniego króla z dynastii Arpadów, Andrzeja III, w styczniu $1301 \mathrm{r}^{52}$ Początkowo wydawało się, że szala zwycięstwa w walce o tron węgierski przechyliła się na korzyść syna króla czeskiego. Młody Wacław został 27 VIII 1301 r. koronowany w Białogrodzie Królewskim na króla Węgier jako Władysław V. Początkowo wspierał go jeden z najznaczniejszych możnych węgierskich, palatyn Amadej, który niebawem jednak, wobec nalegań papieża Bonifacego VIII, postanowił poprzeć papieskiego kandydata, Karola Roberta Andegaweńskiego. Amadej, postać niezwykle ważna już za życia Andrzeja III, po śmierci ostatniego z Arpadów, w wyniku zagarnięcia królewskich regaliów, także w rejonie wydobycia miedzi, stał się jednym z najpotężniejszych ludzi w Europie Środkowej ${ }^{53}$.

s. 596 n.; t e n że, Poslední Přemyslovci a jejich dědictví 1300-1308 (Dvě knihy českých dějin I), wyd. 2, Praha 1926, s. 334 n.; K. M a rá z, Václav III. (1289-1306). Poslední Přemyslovec na českém trůné, České Budějovice 2007, s. 31-44; L. J a n, Václav II. Král na stř́ibrném trůnu 1283-1305, Praha 2015, s. 302 n.; J. Ž e m 1 i č k a, Do tří korun. Poslední rozmach Přemyslovců (1278-1301), Praha 2017, s. 353 n.

${ }^{51}$ Preußisches Urkundenbuch, t. I/2, nr 762; zob. T. J a s i ń s k i, Rola Piastów, s. 61-89.

${ }^{52}$ Sprawy te przedstawił wyczerpująco już J. D ą b r o w s k i, Z czasów Łokietka. Studia nad stosunkami polsko-węgierskimi w XIV w., cz. 1, Rozprawy Akademii Umiejętności, Wydział Historyczno-Filozoficzny 59, 1916, s. 300 n.

${ }^{53}$ Genealogię rodu i jego znaczenie przedstawił ostatnio D. B l a nár, Omodejovci strojcovia bitky pri Rozhanovciach, w: Bitka pri Rozhanovciach v kontexte slovenských a uhorských dejín, Košice 2012, s. 54: „Zhromažd’ovaním majetkov a vysokých úradov si postupne vytvoril svoje regionálne panstvo v rámci ktorého priamo ovládal stolice Uh, Abov, Zemplín, Šariš a Spiš. Jeho vplyv a majetky takisto zasahovali aj stolice Turňa, Sabolč, Heveš a Bereg, vd'aka čomu patril medzi najvýznamnejších uhorských magnátov. Na tomto území mu patrilo množstvo majetkov, z ktorých vel'kú čast' však získal svojvol'ným zabratím celých král'ovských ako aj jednotlivých šl'achtických majetkov. Oporou jeho moci a správy na tomto území boli jednak stoličné centrá, ktoré mal pod svojou kontrolouako aj jehopribližne 12 hradov ahrady jeho spojencov a familiárov". 
Wydobycie miedzi na Słowacji koncentrowało się w pobliżu Koszyc, w trzech ośrodkach: Gelnicy (pierwotnie Hnilec), Smolniku oraz Nowej Wsi Spiskiej. Z Gelnicy, głównego ośrodka wydobywczego, do Koszyc prowadziła w średniowieczu droga licząca niespełna $50 \mathrm{~km}$. Z Gelnicy do Smolnika było ok. 30 km, a z tego ostatniego ośrodka do Koszyc prawie $60 \mathrm{~km}$. Najbardziej na wschód i nieco też na północ leży Nowa Wieś Spiska, odległa od Koszyc ok. 90 km. Cały handel koncentrował się w Koszycach, które w 1290 r. uzyskały prawo składu na handel miedzią ${ }^{54}$. Nie można wykluczyć, że część kupców hanzeatyckich - mimo sprzeciwów koszyczan - docierała bezpośrednio do wymienionych ośrodków wydobywczych. Ze źródeł wiemy, że torunianie zaopatrywali się w miedź gelnicką, którą jednak - jak możemy przypuszczać - kupowali w Koszycach. Gelnica była najstarszym ośrodkiem górniczym tego regionu, powstałym jeszcze przed przybyciem tam górników saskich, co nastąpiło $\mathrm{W}$ drugiej połowie XII w. ${ }^{55}$ Wydobywano tu nie tylko miedź, ale także rudę żelaza, ołów, srebro, a nawet rtęć. Towary te, głównie miedź, docierały przede wszystkim do Krakowa, który był głównym centrum handlu miedzią po drugiej stronie Karpat, acz ważnym ośrodkiem tranzytowym był też Nowy Sącz.

Na początku XIV w. nad głównymi ośrodkami wydobywczymi miedzi na Słowacji przejął kontrolę (lub wręcz zagarnął je) wspomniany Amadej ${ }^{56}$. O zasięgu jego władzy nad tym regionem częściowo informuje dokument ugody pomiędzy mieszczanami koszyckimi a synami i wdową po Amedeju z 1311 r. Dokument ten wymienia dobra i przywileje uznane wówczas za zagarnięte wcześniej przez rodzinę Amadejowiców. $\mathrm{Z}$ dokumentu tego dowiadujemy się, że weszli oni w posiadanie wszelkich regaliów na terenie Spisza, Gelnicy i Koszyc ${ }^{57}$, a także dzierżyli królewskie lasy obok Gelnicy (silvae nigrae) ${ }^{58}$. Amadej zarządzał dwoma ważnymi komitatami, Zemplin i Ung. Dysponował też wszelką władzą administracyjną nad targiem w Koszycach, do którego dowożono całą miedź wydobywaną w tej części Słowacji. Jednym słowem

${ }^{54}$ O. H a l a g a, Košice, s. 80-90, poświęca tej sprawie cały rozdział.

${ }_{55}$ M. H o m z a, Rozwój stosunków osadniczo-etnicznych Spiszu we wczesnym średniowieczu, w: Historia Scepusii, t. I, Bratislava-Kraków 2010, s. 175 n.

${ }^{56}$ Drogi rozwoju państw środkowoeuropejskich na początku XIV w. omawia ogólnie S. G aw la s, Möglichkeiten und Methoden herrschaftlicher Politik im östlichen Europa im 14. Jahrhundert, w: Die „Blüte” der Staaten des östlichen Europa im 14. Jahrhundert, Wiesbaden 2004, s. 257-284; o oligarchii na Węgrzech po wymarciu dynastii Arpadów zob. Gy. Kris tó, Die Macht der Territorialherren in Ungarn am Anfang des 14. Jahrhunderts, w: Etudes historiques hongroises 1985 publiées a l'occasion du XVI ${ }^{\mathrm{e}}$ Congres International des Sciences Historiques, Budapest 1985, t. I, s. 597-614.

${ }^{57}$ Codex diplomaticus Hungariae ecclesiasticus ac civilis, wyd. G. Fejér, t. VII, cz. 1, Budae 1832, nr 192: Item quod Scepes, Gylnich, et Cassa cum vniuersis tricesimis, tributis, censibus, et quibusuis obuentionibus libere dimisissent et resignassent D. Regi dicto; neque ad occupationem praedictorum iurium regalium per se vel per alios, publice vel occulte, se de cetero intromitterent. Promisissent etiam et se obligassent, omnia tributa instituere vel alia castra de nouo aedificare in possessionibus propriis vel etiam alienis sine D. Regis licentia speciali. Zob. też zobowiązania Amadejowiców z 3 X 1311 r. (O. H a l a g a, Počiatky Košíc, s. 325-330).

${ }^{58}$ Codex diplomaticus Hungariae t. VII/1, nr 192: Item, quod promisissent, et se obligassent, quod siluas nigras inter Gylnich et Zakala et Cassa existentes et siluam magnam versus Vizla-Pataka, quae regales sunt, libere dimitterent eis ad vtendum. 
całe wydobycie miedzi węgierskiej i cały handel nią na terenie państwa węgierskiego pozostawały w rękach Amadeja. W każdej chwili mógł on ów handel zablokować, o czym świadczą też postanowienia cytowanej ugody z 1311 r., gdy władza tej rodziny uległa już załamaniu na skutek wielu czynników, o których będziemy pisać niżej. Amadejowice musieli obiecać, że nie będą przeszkadzać w targach koszyckich i blokować do nich dostępu: Item quod promissent et se obligassent, forum praedictorum ciuium de Kassa, directe vel indirecte, nullo vnquam tempore impedire, et accedentes ad ipsum forum et recedentes de ipso nullatenus perturbare ${ }^{59}$.

Amadej ze starych czy nowo wzniesionych zamków obserwował każdy krok kupców przybywających w te okolice. Teroryzował kupców przybywających po węgierską miedź. Jak pisze O. Halaga, napadał na targi i na kupców w czasie drogi, konfiskował towary i ustanawiał na nie nowe myta i $\mathrm{cła}^{60}$. Nie respektował wolności gości. Dysponował zamkami w Koszycach i innych centrach handlu i wydobycia miedzi; dzierżył też królewską komorę w Koszycach. W 1303 r. Amadej, będący wówczas najpotężniejszym węgierskim możnowładcą i jednym z najbogatszych ludzi w Europie, opowiedział się ostatecznie za papieskim kandydatem do tronu, Karolem Robertem. Natomiast mieszczanie koszyccy nadzwyczaj energicznie popierali wciąż Władysława V Przemyślidę. W sojuszu z Koszycami pozostawali Sasi spiscy. Także wiele ze szlachty wsparło czeskiego kandydata. Amadejowice rozpoczęli wrogie działania przeciw mieszczanom i kupcom. Niebawem jednak koszyczanie i Sasi, zachęceni wyprawą króla czeskiego Wacława II do Pesztu, przeszli od ataku. Początkowo główne boje toczyły się o zamek Gönc, gdzie Amadej umieścił piętnastoletniego Karola Roberta. Koszyczanie i Sasi spiscy w 1303 r. rozpoczęli oblężenie tego zamku, ale ponieśli tam porażkę, a ich chorągiew z godłem Przemyślidów jako trofeum została zawieziona na Ruś, gdy młody Karol Robert pojechał tam po swoją przyszłą żonę, Marię córkę Kazimierza bytomskiego ${ }^{61}$. Po tej klęsce walki przeniosły się pod Koszyce, które Amadej próbował wszelkimi siłami opanować. Badacze węgierscy przyjmowali nawet, iż Amadej zdobył miasto w 1304 r., O. Halaga jednak wykazał, że brak na to jakichkolwiek dowodów, a stanowisko węgierskich historyków opiera się na błędnej interpretacji jednego $\mathrm{z}$ dokumentów ${ }^{62}$.

Opór stawiany przez mieszczan koszyckich skłonił Amadeja do zorganizowania wyprawy Władysława Łokietka do Małopolski. Celem tej akcji było nie tylko uderzenie w Przemyślidów, ale przede wszystkim opanowanie głównego centrum i węzła komunikacyjnego w handlu miedzią po drugiej stronie Karpat, a mianowicie Krakowa. Amadej zdawał sobie sprawę, że opanowanie Krakowa złamie opór koszyczan i Sasów spiskich. Zdaniem O. Halagi wojsko Władysława Łokietka przed wyruszeniem do Małopolski stacjonowało w dobrach Amadeja w zachodniej Słowacji. Według tego uczonego sami Amadejowice i ich klientela oraz ich poddani stanowili główny trzon wojska Władysława Łokietka ${ }^{63}$. Atak Władysława Łokietka na Małopolskę był najpewniej rezultatem porozumienia stronników Karola Roberta zawartego w sierpniu

59 Tamże. Zob. też O. H a l a g a, Košice, s. 325 n., gdzie nowa edycja.

60 Tamże, s. 74 n.

${ }^{61}$ Tamże, s. 76; o małżeństwie tym zob. niżej, przyp. 102-113.

${ }^{62}$ O. H a l a g a, Boj Košic, s. 329.

${ }^{63}$ Tamże, s. 330. 
1304 r. w Bratysławie co do wspólnego i skoordynowanego ataku na ziemie Przemyślidów. We wrześniu tego roku równocześnie Węgrzy i Austriacy uderzyli na Morawy, a przez Zemplin wkroczyły do Małopolski oddziały Łokietka z posiłkami Amadejowiców. Wojska węgierskie i austriackie zostały wyparte z Moraw, ale atak Łokietka zakończył się sukcesem. O roli Amadeja w tej wyprawie informuje kilka źródeł, w tym głównie Jan Długosz, który pod 1304 r. pisał, że książę Władysław „zachęcony pomocą Amadeja, z którego gościny korzystał, udaje się do Polski i zajmuje należący do katedry krakowskiej, a zagrażający miastu Wiślicy gród Pełczyska, a następnie dzięki poparciu miejscowej ludności wygania i wypędza załogę czeską z Wiślicy"64. Informację o roli Amadeja potwierdza Rocznik miechowski, w którym czytamy pod 1306 r.: dux Wladislaus dictus Loctek intrat Cracouiam cum iuvamine cuiusdam Vngari dicti Amadey ${ }^{65}$. Pomoc Amadeja znalazła też odbicie w dokumentach wystawionych w tym czasie przez Władysława Łokietka, które stały się przedmiotem oddzielnego opracowania autorstwa Stanisława A. Sroki ${ }^{66}$. Mianowicie w 1304 r. Władysław Łokietek nadał rycerzowi węgierskiemu Piotrowi z Dronowa wieś Chmielów (obecnie słow. Chmel’ov, wcześniej węg. Komlous) położoną w komitacie Sáros (obecnie słow. Šariš). Była ona własnością bożogrobców z Miechowa, którzy mieli otrzymać za nią inną posiadłośćc7. Piotr - podobnie jak Amadej - wywodził się z rodu Aba, a jego siedziba rodowa Dronowo (obecnie Drienov) położona była w kluczowym miejscu, na głównej drodze miedzianego szlaku prowadzącego za Karpaty, między Koszycami a Preszowem. Nadanie to zostało ponowione 1 II 1305 r., już w małopolskiej Wiślicy. W dokumencie tym czytamy, że książę Władysław nadał tę wieś Piotrowi i jego bratu Janowi dlatego, ,iż podziwia wierne i drogie przysługi, które szlachetny mąż, przyjaciel nasz umiłowany, mistrz Piotr z Dronowa, wraz z bratem swoim nam wielokrotnie i pożytecznie wyświadczał i wyświadcza, mianowicie posyłając nam na pomoc ludzi swoich, którzy codziennie walczą przeciwko wrogom naszym i przelewają własną krew z tytułu naszego honoru" ${ }^{68}$. W 1306 r. książę Władysław nadał z kolei Piotrowi z Dronowa miasto Opatów, będące wówczas własnością biskupstwa lubuskiego ${ }^{69}$. To zatem dzięki pomocy Amadeja,

${ }^{64}$ Joannis Dlugossii Annales seu cronicae incliti Regni Poloniae, lib. IX, Warszawa 1978, s. 26; tłum. pol.: Jana Długosza Roczniki czyli kroniki sławnego Królestwa Polskiego, ks. IX, Warszawa 1975, s. $31 \mathrm{n}$.

${ }^{65}$ Z. B u d k o w a, Rocznik miechowski, Studia Źródłoznawcze 5, 1961, s. 124.

${ }^{66}$ S. A. S r o k a, Kontakty Władysława Łokietka z Węgrami w świetle nowych dokumentów, Studia Historyczne 38, 1995, s. 299-307.

${ }^{67}$ Dokumenty polskie z archiwów dawnego Królestwa Węgier, wyd. S. A. Sroka, t. I, Kraków 1998, nr 6: Privilegium domini Wladislay ducis Polonie anno domini MCCC quarto super collacione ville Komlous de Sarys condam Petro filio Georgy--facta; zob. S. A. S r o k a, Kontakty, s. 305, gdzie uwagi co do daty.

${ }^{68}$ Quod intuentes fidelia grataque obsequia, que nobilis vir amicus noster dilectus, magister Petrus de Dronow una cum fratre suo Johanne nobis multipliciter et utiliter exhibuit et exhibet, videlicet mittendo homines suos nobis in auxilium, qui cotidie pugnant contra inimicos nostros et profundunt sanguinem ipsorum racione honoris nostri-dokument był wielokrotnie wydawany (J. D ą b r o w s k i, Z czasów Łokietka, s. 308; Zbiór dokumentów małopolskich, wyd. S. Kuraś, I. Sułkowska-Kuraś, t. IV, Wrocław 1969, nr 889; Dokumenty polskie z archiwów Królestwa Węgier, t. I, nr 7).

${ }^{69}$ Dokument polskie $\mathrm{z}$ archiwów Królestwa Węgier, t. I, $\mathrm{nr} 8$. 
zarówno finansowej, jak i militarnej, Władysław Łokietek dokonywał spektakularnych postępów w opanowywaniu Małopolski, ziemi sieradzkiej i łęczyckiej, Kujaw i Pomorza Gdańskiego. Poważny, a może i decydujący udział w sukcesach Władysława Łokietka miały niewątpliwie sprawy gospodarcze. Trzeba zauważyć, iż przez wszystkie z wymienionych ziem przebiegał szlak handlowy, którym transportowano miedź do Europy Zachodniej. Powszechnie musiano zdawać sobie sprawę z potęgi politycznej i gospodarczej protektora Władysława Łokietka, palatyna Amadeja; dla wszystkich musiało być też oczywiste, że jakiekolwiek przeciwstawianie się władzy Łokietka niesie za sobą poważne konsekwencje dla prawidłowego funkcjonowania tego szlaku handlowego. Zastanawiające, że Władysławowi Łokietkowi udało się wtedy szybko podporządkować te właśnie ziemie, przez które biegł interesujący nas szlak, a więc Małopolskę, ziemie sieradzką i łęczycką, Kujawy i Pomorze Gdańskie. Poza jego zasięgiem pozostała np. główna część Wielkopolski, która nie leżała na szlaku miedzianym. To wyjaśniano zawsze żalami Wielkopolan wobec Łokietka ${ }^{70}$. Wielkopolska nie była w każdym razie tak zainteresowana podporządkowaniem się Łokietkowi, jak ziemie leżące przy owym szlaku.

O tym, że w momencie przejmowania wymienionych ziem przez Łokietka handel miedzią odgrywał kluczową rolę, świadczy dokument wystawiony przez tegoż księcia dla mieszczan krakowskich 12 IX 1306 r., w niecałe dwa tygodnie po ostatecznym uznaniu jego władzy w Małopolsce, gdy już a terrigenis, episcopo et civibus unanimiter susceptus, Cravovie et Sandomirie ducatus obtinuit. W dokumencie tym Łokietek zapewnił kupcom przejeżdżającym przez Kraków pełną swobodę sprzedaży wszystkich towarów wszelkim kupującym, z wyjątkiem jednego towaru - a mianowicie miedzi. Dowiadujemy się, że była ona wieziona do Krakowa z Węgier lub Nowego Sącza (czyli też z Węgier) i dalej drogą wodną lub lądową do Torunia ${ }^{71}$. Dokument ten nie pozostawia żadnej wątpliwości, iż już nie Gdańsk czy ewentualnie Elbląg, a jedynie Toruń był punktem docelowym dla tych kupców. Oczywiście nie oznacza to, że wszyscy inni kupcy poza toruńskimi zostali całkowicie wyłączeni z bezpośredniego handlu z Flandrią ${ }^{72}$. Nie ulega jednak wątpliwości, iż kupcy toruńscy, a jak wiadomo byli to głównie patrycjusze Starego Miasta, pochodzący z Dortmundu i Soestu, odgrywali teraz najważniejszą rolę w dalszym transportowaniu węgierskiej miedzi z Torunia do Flandrii. Na mocy tego dokumentu miedź z Węgier musiała

${ }^{70}$ J. B i e n i a k, Wielkopolska, s. 210 n.; T. J u r e k, Dziedzic Królestwa Polskiego. Książę głogowski Henryk (1274-1309), wyd. 2, Kraków 2006, s. 110; t e n ż e, Polska droga, s. 181.

${ }^{71}$ Kodeks dyplomatyczny miasta Krakowa, wyd. F. Piekosiński, t. I, Kraków 1879, nr 4: Volumus eciam et promittimus, ut omnes mercatores de quibuscumque regionum partibus cum mercibus ad dictam uenientes ciuitatem, omnia ipsorum mercimonia siue merces vendere possunt hospitibus extraneis, uel aliis ementibus quibuscumque, excepto solo cupro, si adductum fuerit de Hungaria uel de Sandecz, uel de quibuscumque aliarum regionum partibus siue locis, nulli extraneo, nisi ciuibus nostris Cracouiensibus debet vendi; et dicti mercatores nullatenus, nisi rebus et mercibus venditis, dictam nostram ciuitatem Cracouiensem audeat pertransire. Ceterum addimus, ut predicti mercatores de Hungaria uel de Sandecz, et de locis aliis quibusqumque cum cupro et aliis mercibus uersus Thorun super aquis non audeant nauigare, neque in terra deducere, nisi prius dictum cuprum et merciminia Cracouie deductum deponantur et ibidem . . ciuibus nostris vendantur, prout superius est expressum.

${ }^{72}$ Zob. niżej, przyp. 91. 
być sprzedana kupcom krakowskim. Prawo to, zdaniem O. Halagi, wymierzone było przeciwko kupcom koszyckim i ustanowione zostało jako kara wymierzona w koszyczan na prośbę Amadeja. Władysław Łokietek odwdzięczył się tym Amadejowicom. Zdaniem tego badacza dokument ów wywarł ogromne wrażenie na koszyczanach i spowodował, iż część z nich przeszła teraz na stronę Amadeja. Od tego momentu miały w Koszycach działać dwa stronnictwa: jedno wciąż przeciwne Amadejowi, a drugie pragnące pogodzenia się z wszechwładnym palatynem ${ }^{73}$.

Niełatwo ocenić krakowskie prawo składu. Zdaniem Stanisława Kutrzeby było ono wymierzone głównie w kupców toruńskich, którym zamknęło bezpośrednie stosunki z Węgrami ${ }^{74}$. Badacz ten zauważa, że gdy na skutek buntu wójta Alberta mieszczanie krakowscy utracili to prawo, to przynajmniej chwilowo główną rolę zaczęli odgrywać kupcy sądeccy, którzy już wcześniej omijali Kraków, wykorzystując drogę wodną Dunajcem i Wisłą.

\section{DALEKOSIĘŻNE SKUTKI POJAWIENIA SIĘ WESTFALCZYKÓW W 1304/1305 R. W STARYM MIEŚCIE TORUNIU}

W świetle dotychczasowych ustaleń nie ulega wątpliwości, że przejęcie władzy w Starym Mieście Toruniu przez mieszczan z Dortmundu i Soestu było szczególnie znaczącym wydarzeniem. Konieczne jest zatem wyjaśnienie, czy był to akt wrogi, czy też przyjazny w stosunku do Lubeki, a także Władysława Łokietka. Wcześniej przypuszczałem, że to właśnie wówczas dzięki pośrednictwu lubeczan Zakon Krzyżacki nawiązał kontakty z patrycjuszami Dortmundu i Soestu, w wyniku czego doszło do osiedlenia się ich w Toruniu w 1304/1305 r. ${ }^{75}$ Pogłębione studia nad stosunkami Lubeki z Soestem i Dortmundem przekonały mnie jednak, że patrycjusze Dortmundu i Soestu, nawiązując ścisłą współpracę gospodarczą ze Starym Miastem Toruniem i innymi miastami pruskimi, wykorzystali kryzys gospodarczo-polityczny, który dotknął Lubekę na przełomie XIII i XIV w. Zbadanie tej kwestii jest istotne dla naszych dalszych rozważań z dwóch względów. Po pierwsze, pozwala lepiej rozpoznać sytuację polityczną w tej części Europy w przeddzień zajęcia Pomorza Gdańskiego przez Krzyżaków. Po drugie, wyjaśnia, jak doszło do poważnych zmian W przebiegu dróg morskich, którymi dostarczano do Europy Zachodniej miedź z Węgier i szereg innych towarów z Rusi, głównie jej halicko-włodzimierskiej części. Te ostatnie zmiany nie pozostały bez wpływu na sytuację gospodarczą Lubeki i Hamburga, a także wywarły ogromny wpływ na rozwój gospodarczy Polski w XIV w. Może wydaje się to nieprawdopodobne, ale zmiany te przyczyniły się najpierw do gwałtownego rozwoju Królestwa Polskiego, a następnie odegrały też ważną rolę w podziale Europy na dwie strefy gospodarcze.

${ }^{73}$ O. H a la g a, Boj Košic, s. 330: „Po roku [tj. w 1306 r. - TJ] Vladislav už ovládal Krakow, čast' Vel'kopol'ska i Pomoria. Majúc pod kontrolou výnosnú tepnu obchodu košických a spišských kupcov od Popradu po Prusko, už 12. 9. 1306 sa Vladislav odvd'ačoval Omodejovcom za pomoc postihom ich nepriatel'ov v krakovskom sklade tovarov".

${ }^{74}$ S. K u tr z e b a, Handel Krakowa w wiekach średnich, Kraków 1902, s. 28 (przedruk w: tegoż, Finanse i handel średniowiecznego Krakowa, Kraków 2009).

75 T. J a s iń s k i, Rola Piastów, s. 81. 
W literaturze przyjmuje się, że w latach 1297-1307 mieszczaństwo lubeckie przeżywało poważne kłopoty ${ }^{76}$. W tym czasie znacznie skurczył się rynek transakcji rentami w Lubece (z wyjątkiem 1305 r.), co zawsze zwiastowało kłopoty polityczne i gospodarcze. Zewnętrzne i wewnętrzne wydarzenia wojenne ograniczyły znacznie działalność handlową lubeczan na ich dwóch głównych obszarach gospodarczych: we Flandrii i w ośrodkach kupieckich leżących na drodze do Nowogrodu Wielkiego. Na działalności gospodarczej Lubeki odbił się też niekorzystnie długotrwały spór pomiędzy miastem a biskupem Burkhardem von Serkem o posiadłości w najbliższym sąsiedztwie Lubeki i o prawa lenników biskupa w tym regionie ${ }^{77}$. W 1299 r. spór ten osiągnął apogeum; w mieście doszło do tumultu, w wyniku którego biskup został wygnany z Lubeki. W odpowiedzi na to biskup skłonił księcia Ottona II z Lüneburga do zaatakowania Lubeki, która na skutek tego ataku poniosła niemałe straty w ludziach i majątku. Bezpośrednio po tych wydarzeniach lubeczanie musieli swoją uwagę skoncentrować na zapewnieniu bezpieczeństwa najbliższym szlakom komunikacyjnym i przezwyciężeniu chaosu, który ogarnął cały Holsztyn. W 1306 r. doszło do poważnego konfliktu z hrabią holsztyńskim Gerhardem II oraz z książętami meklemburskimi. Miasto zostało zaatakowane; wrogowie opanowali strategicznie położony półwysep Priwall i wznieśli tam własny zamek, skąd grozili w każdej chwili zablokowaniem portu. Sytuacja Lubeki była tak trudna, że jej przywódcy zgodzili się na przyjęcie na okres 10 lat „opieki” ze strony króla duńskiego Eryka VI Menveda, którą to „opiekę” przedłużono w 1316 r. o dalsze cztery lata ${ }^{78}$.

Wszystko wskazuje zatem na to, że patrycjusze Dortmundu i Soestu w 1304/1305 r., osiedlając się w Toruniu i przejmując handel miedzią z Europą Zachodnią, wykorzystali kłopoty, w które popadła wówczas Lubeka. Najpewniej wydarzenia te ułatwiły im zajęcie miejsca kupców Lubeki w handlu miedzią. Osiedlając się w Toruniu, powyżej Gdańska, Westfalczycy uzyskiwali uprzywilejowaną pozycję w stosunku do tamtejszych lubeczan. Wszyscy kupcy zmierzający ze Słowacji na północ, czy to wozami, czy to statkami, mogli sprzedać towar już w Toruniu, skąd dalej był on transportowany do Europy Zachodniej. Po przejęciu handlu miedzią przez toruńskich Westfalczyków była ona dalej transportowana przez Sund, a nie, jak było to wcześniej, przez Lubekę̨

Na podstawie tych faktów można zatem przypuszczać, że kupcy z Dortmundu i Soestu działali nie w porozumieniu z Lubeką, a przeciwko niej. Ponieważ miasta westfalskie i Lubeka były w wielu dziedzinach, a zwłaszcza w handlu z Nowogrodem

${ }^{76}$ A. G r a $ß$ m a n n, Lübeckische Geschichte, Lübeck 1989, s. 180.

77 J. R e e tz, Bistum und Stadt Lübeck um 1300. Die Streitigkeiten und Prozesse unter Burkhard von Serkem, Bischof 1276 bis 1317, Lübeck 1955; t e n że, Nachträge zu den Streitigkeiten zwischen Bistum und Stadt Lübeck um 1300, Zeitschrift des Vereins für Lübeckische Geschichte 45, 1965, s. 133-140; A. G r a ß m a n n, Lübeckische Geschichte, s. 288 n.; W. Ehbrecht, Skizzen und Überlegungen zur älteren Verfassungsgeschichte deutscher Städte, Köln-Weimar-Wien 2001, s. 219; E. I s e n m a n n, Die deutsche Stadt im Mittelalter 1150-1550. Stadtgestalt, Recht, Verfasssung, Stadtregiment, Kirche, Gesellschaft, Wirtschaft, Köln-Weimar-Wien 2014, s. 644 n.

78 A. G r a $ß$ m a n n, Lübeckische Geschichte, s. 130.

${ }^{79}$ K.-O. A h n s e h 1, Thorns Seehandel, s. 51. O rozporządzeniach dotyczących eksportu miedzi przez Lubekę do Flandrii zob. Lübeckisches Urkundenbuch, t. II, nr 106, s. 86. 
Wielkim, ze stacją pośrednią w Visby na Gotlandii, skazane na współpracę, żadna ze stron nie mogła sobie pozwolić na otwarty konflikt. Działano więc obustronnie mimo poważnego naruszania interesów - „w białych rękawiczkach”. Świadectwem jest tu znamienny list rajców Soestu do Lubeki z jesieni 1305 r., w którym odmawiają oni przysłania swoich reprezentantów - co było rzeczą niebywałą - na zjazd przedstawicieli miast hanzeatyckich do Lubeki 10 XI 1305 r. Fakt ten rajcy uzasadniali zaufaniem do poczynań Lubeki i zapowiadali, że podporządkują się wspólnemu stanowisku miast westfalskich, wyrażonemu na wspomnianym zjeździe ${ }^{80}$. Nie można wykluczyć prawdziwości tego usprawiedliwienia, ale list przypada akurat na okres, kiedy Westfalczycy przejmowali jeden z najbardziej dochodowych interesów Lubeki.

Osiedlenie się patrycjuszy z Dortmundu i Soestu w Starym Mieście Toruniu i rozciągnięcie stąd przez nich kontroli nad handlem miedzią węgierską miały wszystko na to wskazuje - niezwykle dalekosiężne skutki dla rozwoju gospodarczego Królestwa Polskiego w XIV w. Odbiło się ono również na rozwoju handlu Hanzy, przede wszystkim na handlu Lubeki z Nowogrodem Wielkim i Visby. Chociaż potwierdzenie tej hipotezy wymagałoby wszechstronnych i kompleksowych badań, to jednak - mimo wielu znaków zapytania - przybliżmy ogólny tok rozumowania $\mathrm{w}$ tej kwestii. Istotną sprawą jest poznanie, choćby w najkrótszym zarysie, dawnych dróg wodno-lądowych z Bałtyku nad Morze Północne ${ }^{81}$. We wczesnym średniowieczu statki płynące ze Wschodu z towarami ze strefy bałtyckiej wpływały do wąskiej i długiej zatoki bałtyckiej (dawnej rynny glacjalnej) - Schlei (duńskie Slien), wcinającej się na ponad $40 \mathrm{~km}$ w Półwysep Jutlandzki. Na końcu tej niezwykłej zatoki, najczęściej o szerokości nieco ponad jednego kilometra, leżał słynny ośrodek handlu wikińskiego - Haithabu (IX w.); tu towary wyładowywano i drogą lądową wieziono do portu rzecznego w Hollingstedt nad rzeką Treene, gdzie towary ponownie ładowano na statki, które płynęły rzeką Treene do rzeki Eider, która uchodziła do Morza Północnego ${ }^{82}$. Jeszcze w czasach dominacji handlu Skandynawów na Bałtyku port w Haithabu uległ całkowitemu zniszczeniu na skutek działań wojennych w 1050 i 1066 r. Po tym ostatnim zniszczeniu Haithabu już nie odbudowano, a jego rolę przejął leżący w pobliżu port w Szlezwiku, na przeciwległym brzegu Schlei. Od tego momentu statki pełnomorskie żeglowały do Szlezwiku, gdzie wyładowywano towary i podobnie jak wcześniej transportowano je drogą lądową do Hollingstedt. Tu nic się nie zmieniło. Do poważnych zmian doszło dopiero po zniszczeniu w czasie wojen duńsko-niemieckich w 1156 Szlezwiku i odbudowie Lubeki po wielkim pożarze z 1157, co nastąpiło w 1159 r. Do tego czasu handel bałtycki, głównie z Nowogrodem Wielkim, był zmonopolizowany w rękach Gotlandczyków, a przejęcie przez Lubekę roli Szlezwiku oddało ten handel w ręce kupców dolnoniemieckich, głównie westfalskich. Zasadniczej zmianie uległ też przebieg dróg pomiędzy Morzem Bałtyckim

${ }^{80}$ Hanserecesse, t. I, Leipzig 1870, nr 83.

${ }^{81}$ W. Voge 1, Geschichte der deutschen Seeschifffahrt, t. I, Berlin 1915, s. 142 n.; tę wielokrotnie wznawianą (ostatnio w 1.2016 i 2017) pracę uznać jednak trzeba za przestarzałą.

${ }^{82} \mathrm{H}$. F a h l b u s ch, Eine Einführung in das Thema der Tagung, w: Wasserstraßen zwischen Elbe, Nord- und Ostsee einst und jetzt und weitere wasserhistorische Beiträge, Siegburg 2011 (Schriften der Deutschen Wasserhistorischen Gesellschaft 17), s. 1. Na marginesie trzeba dodać, że częściowo spławną była rzeczka Rheider Au, dopływ Treene. 
a Morzem Północnym. Lubeka przejęła rolę Haithabu i Szlezwiku, a Hamburg - rolę Hollingstedt. Stąd kariera i rola tych miast w Hanzie. Pełnomorskie statki bałtyckie wpływały rzeką Trawą do Lubeki, gdzie towary przeładowywano i drogą lądową wieziono je do portu w Hamburgu. Niekiedy do dalszego transportu lżejszych towarów wykorzystywano uchodzącą do Trawy rzeczkę Stecknitz, wypływającą z jednego z jezior obok miejscowości Mölln (ok. $30 \mathrm{~km}$ na południe od Lubeki), oraz rzeczkę Delvenau, mającą swoje źródła ok. 6 km poniżej Mölln, obok miejscowości Grambek, a uchodzącą już do Łaby. Rzeczki te wymieniam, gdyż w latach 1392-1398 skanalizowano je i połączono w pierwszy w Europie, a drugi na świecie, kanał (niem. Wasserscheidenkanal) ze śluzami i komorą wodną. Kanał ten służył jednak głównie do transportowania specjalnymi płaskodennymi statkami soli lüneburskiej, towaru strategicznego dla rzemiosł spożywczych krajów nadbałtyckich, a w tym i Polski w średniowieczu i wczesnym okresie nowożytnym. Tak więc generalnie cały handel pomiędzy krajami położonymi nad Morzem Północnym (a więc Flandrią, Anglią, Francją itd.) a krajami nadbałtyckimi (w tym Nowogrodem Wielkim, Smoleńskiem, Połockiem, Inflantami, Prusami, Pomorzem) odbywał się przez Lubekę i Hamburg, gdzie - jak zaznaczyliśmy - wszystkie towary musiały być przeładowywane. Istniała wprawdzie droga przez Sund, ale przez długi czas była ona nieopłacalna. Lubeczanom jeszcze w latach sześćdziesiątych XIV w. opłacało się przewozić całą miedź importowaną ze Szwecji do Flandrii drogą lądową przez Lubekę-Hamburg. Przyjrzyjmy się rozmiarom tego handlu na podstawie zestawienia K.-O. Ahnsehla, który oparł się na wielu opracowaniach źródłowych ${ }^{83}$ :

\begin{tabular}{|c|c|c|c|}
\hline Rok & $\begin{array}{c}\text { Szwecja } \\
\text { (via } \text { Lubeka) }\end{array}$ & $\begin{array}{c}\text { Węgry } \\
\text { (via Torun) }\end{array}$ & $\begin{array}{c}\text { Harz } \\
\text { (via } \text { Hamburg) }\end{array}$ \\
\hline $1362 / 63$ & - & 32780,5 & - \\
\hline 1368 & 4500 & - & - \\
\hline 1369 & 5500 & 9150 & - \\
\hline 1370 & - & 9450 & 520 \\
\hline
\end{tabular}

Źródło: K.-O. Ahnsehl, Thorn Seehandel, s. 51, tab. 16; wartości w grzywnach lubeckich ${ }^{84}$.

Otóż kupcy westfalscy i pruscy transportowali miedź węgierską nie przez Lubekę-Hamburg, lecz drogą przez Sund. Powstaje pytanie, co było tego przyczyną. Jedynym racjonalnym wyjaśnieniem wydaje się przyjęcie hipotezy, że lubeczanie - mimo przynależności miast westfalskich do Hanzy - traktowali te ostatnie jako konkurencję i z tego powodu utrudniali im w większym lub mniejszym zakresie dostęp do kontrolowanej przez siebie drogi Lubeka-Hamburg. Bardzo możliwe, że zagarnięcie przez Westfalczyków handlu miedzią węgierską kosztem Lubeki na początku XIV w. skłoniło ostatecznie lubeczan do wprowadzenia przeciwko Westfalczykom restrykcji, które szczególnie uwidoczniły się właśnie w handlu miedzią.

${ }^{83}$ M.in. na podstawie Das Hamburgische Pfundzollbuch von 1369, opr. H. Nirrnheim, Hamburg 1910 (Veröffentlichungen aus dem Staatsarchiv der Freien und Hansestadt Hamburg 1) oraz pruskich wykazów cła funtowego.

${ }^{84}$ Tę samą tabelę w języku słowackim zamieszcza O. H a l a g a, Košice, s. 172. 
O tym, że Westfalczycy najpewniej już w 1305 r. skierowali swoje statki przez Sund, świadczy występowanie w tym roku wśród westfalskich rajców w Starym Mieście Toruniu Bertolda z Kopenhagi (Bertoldus de Copenhauen), a więc z portu, który zawdzięczał swoją pomyślność rozwojowi żeglugi sundzkiej.

Na chwilę wiślanym transportem miedzi wstrząsnęły wydarzenia związane z zajęciem Pomorza Gdańskiego przez Krzyżaków w 1308 i 1309 r. Westfalczycy uważnie obserwowali zmieniający się układ sił politycznych u ujścia Wisły. Początkowo wydawało się, że Pomorze Gdańskie opanują Brandenburczycy. W końcu sierpnia lub na początku września 1308 r. zajęli oni Gdańsk, ale z wyjątkiem grodu ${ }^{85}$. Być może akcja ta zakończyłaby się sukcesem, gdyby nie fakt, iż uwagę margrabiów brandenburskich od spraw pomorskich odciągnęły wydarzenia ogólnoniemieckie. Margrabia Waldemar musiał udać się do Frankfurtu nad Menem, gdzie 27 XI 1308 r. uczestniczył w wyborze nowego króla niemieckiego Henryka VII Luksemburskiego. Gdy w październiku 1308 r. młody margrabia Waldemar udawał się na zachód Niemiec, oddziały brandenburskie opuściły Gdańsk pod naporem wojsk krzyżackich, które przybyły na odsiecz na prośbę Władysława Łokietka. W Soest nie wiedziano jednak, jak ostatecznie rozwinie się sytuacja u ujścia Wisły, tym bardziej że gdańszczanie nie wpuścili Krzyżaków do miasta i ciągle czekali na posiłki brandenburskie, a stronnicy Brandenburgii trzymali się w oblężonym mieście ${ }^{86}$. Gdy więc 21 I 1309 r. wracający z elekcji margrabia Waldemar przejeżdżał przez Soest, tutejsi mieszczanie wymogli na nim przywilej, który brał miejscowych kupców pod szczególną opiekę i gwarantował im zwolnienie od prawa brzegowego (ius naufragii) ${ }^{87}$. Oczywiście przywilej ten miał wielkie znaczenie dla kupców miasta Soest tylko w wypadku, gdyby Brandenburczycy opanowali Pomorze Gdańskie z ujściem Wisły.

Zajęcie Pomorza Gdańskiego doczekało się wielu opracowań, które wyczerpująco przedstawiają tę problematykę. Nie ma potrzeby, aby powracać do opisu tych wydarzeń. Z naszego punktu widzenia zastanawia tylko jeden fakt: dlaczego mianowicie Krzyżacy zdecydowali się na całkowite zniszczenie Gdańska, a także Tczewa? W nocy z 12 na 13 XI 1308 r. wojska krzyżackie wzięły szturmem miasto Gdańsk. Zniszczenia były niemałe. Krzyżacy jednak się do tego nie ograniczyli ${ }^{88}$.

${ }^{85}$ K. J a s i ń s k i, Zajęcie Pomorza Gdańskiego przez Krzyżaków w latach 1308-1309, Zapiski Historyczne 31, 1966, s. 16 n.; B. Śli w iń s k i, Rzeź i zniszczenie Gdańska przez Krzyżaków w 1308 roku, Gdańsk 2006, s. 132 n.; t e n ż e, Wydarzenia w Gdańsku i w okolicach w okresie od września do 12/13 listopada 1308 roku, w: „Rzeź gdańska” (jak w przyp. 37), s. 79 n.

86 Tamże, s. 95.

87 PllUB nr 666: Volentes eis nostrum affectum in effectu demonstrare predictos cives Sisatenses recepimus et litteris presentibus recipimus in nostram protectionem et graciam specialem, talem videlicet, quod, in quocumque loco nostrarum terrarum naufragii periculum inciderint, omnia bona, que suis laboribus et sumptibus de periculo maris vel fluminum quorumcunque eripuerint cessante cuiuslibet contradictionis obstaculo sibi integra remanebunt et quilibet eis ad talium bonorum erepcionem cooperans pro suis laboribus et sumptibus recepta mercede graciosa nichil amplius de bonis talibus usurpabit.

${ }^{88} \mathrm{~K}$. J a s iń s k i, Zajęcie, s. 7 n.; t e n ż e, Zburzenie miasta Gdańska przez zakon krzyżacki w 1308 r., Zapiski Historyczne 41, 1976, z. 3, s. 25 n.; B. Śliw iń s ki, Pomorze Wschodnie, s. 608; t e n że, Rzeź, s. 132; t e nże, Wydarzenia, s. 79 n. 
Mieszczanie, jak wiemy to z zeznań prokuratora krzyżackiego, zostali zmuszeni do rozebrania budynków i opuszczenia miasta. Miasto Gdańsk przestało istnieć i nie było go aż do początków lat trzydziestych XIV w. Następnie, już bez walki, poddał się Zakonowi Tczew, również będący, podobnie jak Gdańsk, miastem na prawie lubeckim. Mieszczanie Tczewa zostali zobowiązani do opuszczenia miasta do najbliższych Zielonych Świątek (18 V 1309) i zakazano im osiedlania się na terenie państwa Zakonu w Prusach ${ }^{89}$. Różnie w literaturze tłumaczono te posunięcia; zwracano uwagę, że Krzyżacy liczyli się z koniecznością ustąpienia z Pomorza, a obydwa miasta, zwłaszcza Gdańsk, uważali za groźną konkurencję ${ }^{90}$. Obecnie możemy dodać, że zniszczenie Gdańska, a także Tczewa oznaczało całkowite oddanie handlu miedzią w ręce torunian. Jak wiemy, patrycjat toruński już w 1306 r., jak wynika to z przytaczanego dokumentu Łokietka z 12 IX 1306 r., odgrywał w tym handlu główną rolę, ale być może ciągle istniało dla torunian niebezpieczeństwo konkurencji ze strony Gdańska. Nie wiemy jednak, czy obawy te miały jakieś znaczenie przy podjęciu decyzji przez Zakon o zniszczeniu Gdańska i Tczewa.

Zajęcie Pomorza Gdańskiego znacznie utrudniło kupcom transport miedzi po północnej stronie Karpat. Dotąd kupcy od przekroczenia gór podróżowali cały czas przez ziemie podległe Władysławowi Łokietkowi, choć w wypadku wyboru drogi wodnej na pewnym obszarze żeglowali przez terytorium księcia Bolesława II mazowieckiego, a na krótkim odcinku także księcia Siemowita dobrzyńskiego czy Krzyżaków. W czasie walk o Świecie, które miały miejsce późnym latem 1309 r., statki mieszczan krakowskich, płynące z Flandrii do Krakowa, zostały zatrzymane przez wojska krzyżackie. Zarówno same statki, jak i towary zostały zarekwirowane, a Krzyżacy oddali je dopiero po zdobyciu grodu świeckiego. Jeden z poszkodowanych wtedy mieszczan wspominał, iż odzyskał towary, tantum stetit erga magistrum, videlicet per VIII dies ${ }^{11}$. Jak widzimy, walki o Pomorze Gdańskie, a następnie jego zajęcie, utrudniły kupcom krakowskim łączność z Flandrią. Z podobnymi utrudnieniami ze strony Łokietka mogli liczyć się kupcy westfalscy osiadli w Toruniu. Zapewne to z tymi obawami należy wiązać powstanie w 1309 r. szlaku handlowego przez ziemie księcia mazowieckiego Bolesława II, w tym i przez Warszawę, na Ruś i na Węgry. Początkowo uważałem, że był to wyłącznie szlak z Torunia do Włodzimierza Wołyńskiego, w związku z czym przyjmowałem, że chodziło tu jedynie o przesunięcie dawnego szlaku biegnącego wzdłuż Bugu na nową oś wzdłuż Wisły i przez Warszawę̨2. Gdy jednak bliżej przyjrzymy się przywilejowi Bolesława II z 22 II 1310 r., drugiemu, niedatowanemu dokumentowi tegoż księcia oraz przywilejowi księcia Trojdena z 28 II 1311 r. ${ }^{93}$,

${ }^{89}$ Preußisches Urkundenbuch, t. I/2, nr 901. Zob. K. J a s iński, Zburzenie; B. Śli w ińs k i, Data zburzenia Gdańska przez Zakon Krzyżacki, Kwartalnik Historyczny 96, 1990, nr 3-4, s. 181-185.

${ }^{90}$ Tak np. G. Labuda, Walka o Pomorze Gdańskie na przełomie XIII i XIV wieku, w: Historia Pomorza, t. I, cz. 1, Poznań 1969, s. 544.

${ }^{91}$ Lites ac res gestae inter Polonos Ordinemque Cruciferorum, wyd. 2, t. I, [wyd. I. Zakrzewski], Poznań 1890, s. 383-384.

${ }_{92} \mathrm{O}$ znaczenie tego szlaku i jego powstaniu zob. T. J a s i ń s k i, Rola Piastów, s. 61-89.

${ }_{93}$ Nowy kodeks dyplomatyczny Mazowsza, cz. II, wyd. I. Sułkowska-Kuraś, S. Kuraś, Wrocław 1989, nr 123, 126, 136. 
wówczas nie ulega wątpliwości, że chodziło w nich też o biegnącą przez Mazowsze drogę okrężną, która transportowano towary z Węgier, a więc przede wszystkim miedź ${ }^{4}$. Powstanie tego szlaku łatwo wydatować na wczesną jesień 1309 r. Pierwszy dokument, który ujawnia zbliżenie krzyżacko-mazowieckie, w tym wypadku patrycjatu toruńskiego z biskupem płockim, pochodzi z 1 X 1309 r. Został więc wystawiony zaledwie kilka dni po zdobyciu przez Krzyżaków Świecia, którego bronili najpewniej też rycerze wysłani przez Bolesława mazowieckiego. Szlak ten miał wyraźnie za zadanie zastąpienie lądowych dróg biegnących przez tereny pozostające pod rządami Władysława Łokietka. Wydaje się, że powstanie tej nowej drogi było następstwem zajęcia Pomorza przez Krzyżaków i doświadczeń czy incydentów zaistniałych w czasie walk o Świecie. Szlak ten z pewnością działał przez kilka lat na szkodę Władysława Łokietka. Z czasem jednak, najpóźniej w 1315 r., miedziany szlak powrócił na ziemie Łokietkowe, ale i jego mazowiecka odnoga nie upadła, gdyż od samego początku kupcy toruńscy, głównie westfalskiego pochodzenia, podążali nią na Ruś, do Włodzimierza Wołyńskiego, gdzie spotykali kupców weneckich i genueńskich, przybywających z kantorów nad Morzem Czarnym, z Tamy, Kaffy, a nawet z Konstantynopola. Szlakiem tym sprowadzano towary, które lubeczanie musieli pozyskiwać w dalekim Nowogrodzie Wielkim i, jak było to już powiedziane, w drodze do Flandrii przeładowywać ze statków na wozy i ponownie z wozów na statki na drodze lądowej pomiędzy Lubeką a Hamburgiem. Głównym towarem sprowadzanym z Wołynia był, obok skórek, wosk. Połączenie handlowe Toruń - Włodzimierz Wołyński, a później Toruń-Lwów otworzyło przed kapitałem westfalskim, a głównie przed kupcami z Dortmundu, nowe możliwości ekspansji gospodarczej. Przyczyniało się to zarazem do rozwoju gospodarczego Królestwa Polskiego, Mazowsza, Węgier (głównie rejonu Koszyc), Prus, Flandrii, Anglii, a także, jak zobaczymy, Belgii (Hennegau) i Holandii. Zmonopolizowanie handlu z Węgrami (m.in. miedzią) oraz Rusią (m.in. woskiem itd.) przez Westfalczyków toruńskich, wspieranych przez kupców westfalskich, przede wszystkim z Dortmundu i Soestu, doprowadziło do powstania w ramach Hanzy kupieckiej wspólnoty prusko-westfalskiej. Wspólnota ta - zanim jeszcze przybrała instytucjonalną postać - podjęła nowe kierunki ekspansji. O wspólnocie kupców westfalskich i pruskich mówi wyraźnie przywilej wystawiony 22 V $1340 \mathrm{r}$. w Brukseli przez Wilhelma IV, hrabiego z Hennegau i Holandii. Obdarzył on wieloma przywilejami i wziął w opiekę ghemeine coeplude van Prussen ende van Westvalen, m.in. obniżył cła w Dordrechcie na wiele towarów, w tym na miedź ${ }^{95}$. Było to niezwykle istotne, gdyż właśnie poprzez Dordrecht, położony nad wspólną deltą Renu i Mozy, kupcy westfalscy i pruscy, mogli płynąć w górę Mozy aż kilkaset kilometrów. Hrabia Wilhelm nadał im zresztą szereg przywilejów związanych z żeglugą na Mozie. Niebawem wspólnota prusko-westfalska przybrała formę instytucjonalną w postaci wspólnego okręgu miast westfalsko-pruskich w kantorze w Brugii. „Instytucje okręgów odnotowuje się po raz pierwszy w regulaminie kantoru w Brugii z 1347 roku. W kantorze tym kupcy grupowali się według miejsca pochodzenia $\mathrm{w}$ trzech okręgach - lubecko-saksońskim,

\footnotetext{
${ }^{94}$ Tamże, nr 123: et ceteris civitatibus terre Cracouiensis et Vngarie.

95 Hansisches Urkundenbuch, t. II, nr 658, 674.
} 
westfalsko-pruskim i gotlandzko-inflanckim"96. Wspólnota ta nie była, jak przypuszczają niektórzy badacze, jakimś przypadkowym rozwiązaniem na potrzeby regulaminu w Brugii, lecz wynikała z rzeczywistych interesów gospodarczych.

Towary ruskie i węgierskie transportowane przez kupców pruskich, w tym głównie toruńskich westfalskiego pochodzenia, trafiały nie tylko do Flandrii czy Holandii, ale przede wszystkim do Anglii, głównie do Londynu. Oczywiście zorganizowanie całej sieci szlaków handlowych, łączących Wschód z Zachodem nie byłoby możliwe bez ogromnego zaangażowania i kapitału miast westfalskich, z Dortmundem na czele. O dochodach kupców westfalskich najlepiej świadczy ich działalność o charakterze bankowym na terenie Anglii. W 1338 r. czterech kupców z Dortmundu, w tym dwóch Sudermannów (przedstawiciele tej rodziny byli obecni w Krakowie od 1302 r.), pożyczyło królowi angielskiemu Edwardowi III 1200 funtów. Jeszcze w tym samym roku otrzymał on od kupców dortmundzkich dodatkową pożyczkę w wysokości 5000 funtów. Rok później konsorcjum kupców, złożone głównie z Westfalczyków, udzieliło królowi pożyczki ponad 18000 funtów. Nie były to ostatnie pieniądze pożyczone w tym czasie królowi Anglii. Ostatecznie kupcy westfalscy w 1344 r. wykupili Edwardowi zastawioną koronę i inne insygnia królewskie za blisko 50000 florenów (ok. 7500 funtów) ${ }^{97}$.

Omijanie przez Westfalczyków przeprawy Lubeka-Hamburg i kierowanie przez nich statków do Prus przez Sund miało dalekosiężne skutki. Znawca handlu strefy nadbałtyckiej z Flandrią, Fritz Renken, scharakteryzował je następująco: „So begegneten und ergänzten sich seit der Mitte des 14. Jahrhunderts die Interessen Preußens und Englands aufs günstigste und bewirkten jene starke Belebung der Handelslinie Ordensland-Sund-England, die der alten Linie Nowgorod-Lübeck-Hamburg-Brügge so schweren Eintrag tun sollte" ${ }^{98}$. Niebawem, jeszcze w XIV w., Westfalczycy sięgnęli do frachtu holenderskiego ${ }^{99}$. Później za Holendrami przyszły przedsiębiorstwa kupieckie z Anglii. Masowo zaczęto importować z Królestwa Polskiego i Wielkiego Księstwa Litewskiego zboże, co, jak wiadomo, wpłynęło na powstawanie folwarków i rozwój pańszczyzny, a Europa podzieliła się na dwie strefy gospodarcze i społeczne ${ }^{100}$. Oczywiście w tych procesach nie uczestniczyli już Westfalczycy, ale to ich działalność, a zwłaszcza przejęcie szlaku miedzianego i dróg na Ruś, dało do tych zmian istotny impuls.

${ }^{96}$ Ph. D o 11 i n g e r, Dzieje Hanzy XII-XVII w., thum. V. Soczewińska, Warszawa 1997, s. 93; zob. też R. C z a j a, Udział, cz. 2, s. 48 n., oraz A. K i e B e 1 b a c h, Die wirtschaftlichen Grundlagen der deutschen Hanse und die Handelsstellung Hamburg, Berlin 1907, s. 191 n.

${ }^{97}$ Ph. D o 11 in g e r, Dzieje Hanzy, s. 61.

${ }^{98}$ F. R e n k e n, Der Handel der Königsberger Grossschäfferei des Deutschen Ordens mit Flander um 1400, Weimar 1937, s. 17; zob. też tamże: „Diese Verbindung Preußen-Flander mochte anfangs sich gebunden haben an den Umschlag in Lübeck oder auf den Schonenschen Messen - aber durch die Art der Waren wurde auch diese Handelsverbindung zu einem die althansische Tradition durchbrechenden Faktor: die preußisch-baltischen Massengüter mußten naturgemäß den Umschlag in Lübeck und Hamburg meiden und due Sundfahrt wöhlen".

${ }_{99}$ R. C z a j a, Udział, cz. 2, s. 48 n.

100 Przegląd starszych badań i najnowszy punkt widzenia na te zagadnienia przedstawia zbiór: Ziemie polskie wobec Zachodu. Studia nad rozwojem średniowiecznej Europy, red. S. Gawlas, Warszawa 2006, gdzie zwłaszcza R. C z a j a, Strefa bałtycka w gospodarce europejskiej w XIII-XIV wieku ze szczególnym uwzględnieniem Prus krzyżackich, s. 195-245. 


\section{BUNT WÓJTA ALBERTA}

Mając świadomość znaczenia uwarunkowań gospodarczych dla pierwszych lat panowania Władysława Łokietka w Królestwie Polskim, przyjrzyjmy się buntowi wójta Alberta w latach 1311-1312 ${ }^{101}$. Zanim jednak przejdziemy do omówienia jego genezy i przebiegu, konieczne jest choćby skrótowe wyjaśnienie pewnych wątpliwości związanych z małżeństwem króla węgierskiego Karola Roberta z księżniczką Marią, córką księcia Kazimierza bytomskiego. Dla naszych rozważań związanych z sytuacją polityczną władztwa Władysława Łokietka w latach 1304-1312 małżeństwo Marii ma wielkie znaczenie. Mariaż ten był przedmiotem licznych badań. Wiele uwagi poświęcił mu Stanisław A. Sroka ${ }^{102}$. Jego ustalenia nie pozostawiają wątpliwości, iż Maria była pierwszą żoną Karola Roberta, jak od dawna sądzono, a co zanegował historyk węgierski Gyula Kristó na podstawie dwóch przekazów ${ }^{103}$. S. A. Sroka wykazał jednak ponad wszelką wątpliwość błędność tego poglądu. Uznał Marię - tak jak tradycyjnie przyjmowano - za córkę Kazimierza bytomskiego i niezidentyfikowanej Heleny. Tę ostatnią, idąc za Kazimierzem Jasińskim, z którym w tej sprawie korespondował, gotów był uznać za córkę księcia halickiego Lwa ${ }^{104}$. Najpewniej z tego względu Maria wychowywała się - przynajmniej przez krótki czas - na Rusi, gdzie Karol Robert udał się, aby ją poślubić, jak to wynika z pewnego

${ }^{101}$ Dla całego zagadnienia buntu wójta Alberta podstawowe znaczenie mają prace: E. D ł u g o p o 1 s k i, Bunt wójta Alberta, Rocznik Krakowski 7, 1905, s. 135-186 i odbitka; t e n że, Władysław Łokietek, s. 135-164; J. W y r o z u m s k i, Dzieje Krakowa, t. I, Kraków 1992, s. 199-211. Por. też M. B o br z yń s k i, Bunt wójta krakowskiego Alberta z roku 1311, w: tegoż, Szkice i studia historyczne, t. I, Kraków 1922, s. 159-183; M. N i w i ń s k i, Wójtostwo krakowskie w wiekach średnich, Kraków 1938, s. 41-43; A. Kło d z i ń s k i, Jeden czy dwa bunty wójta Alberta?, w: Studia historyczne ku czci Stanisława Kutrzeby, t. II, Kraków 1938, s. 339-356; t e n ż e, Z dziejów pierwszego krakowskiego buntu wójta Alberta, Zapiski Towarzystwa Naukowego w Toruniu 14, 1948, z. 1, s. 45-56; J. B a s z k i e w i c z, Powstanie, s. 354 n.; S. G a w l a s, O kształt zjednoczonego Królestwa. Niemieckie władztwo terytorialne a geneza społeczno-ustrojowej odrębności Polski, Warszawa 1996, s. 94. Od dokładnego omówienia stanu badań zwalnia niedawne ukazanie się zbioru: Bunt wójta Alberta. Kraków i Opole we wzajemnych związkach w XIV w., Kraków 2013 (Annales Universitatis Paedagogicae Cracoviensis, Studia Historica 13), gdzie zob. zwłaszcza: A. Grab ow s k a, Bunt wójta Alberta w historiografii polskiej, s. 19-31.

102 S. A. S r o k a, Wokół mariażu Karola Roberta z Piastówną śląską Marią, Biuletyn Polskiego Towarzystwa Heraldycznego 11, 1994, s. 1-5; t e n ż e, Ki volt Károly Róbert elsö felesége?, Aetas 1, 1994, s. 187-193; t e n ż e, A Hungarian-Galician mariage at the beginning of the fourteenth century?, Harvard Ukrainian Studies 16, 1994, s. 261-268; t e n że, Piastówna śląska Maria, królową Węgier, w: tegoż, Z dziejów stosunków polsko-węgierskich w późnym średniowieczu. Szkice, Kraków 1995, s. 29-48; t e n ż e, Genealogia Andegawenów węgierskich, Kraków 1999; t e n ż e, Чи існувала руська дружина угорського короля Карла Роберта на початку XIV століття?, Княжа доба 3, 2010, s. 268-277. Zob. też K. J a s i ń s k i, Rodowód Piastów śląskich, wyd. 2, Kraków 2007, s. 534-535; t e n ż e, Maria, w: Polski słownik biograficzny, t. XX (1975), s. 3.

${ }^{103}$ Gy. K r i s t ó, Károly Róbert elsö felesé, Acta Universitatis Szegediensis de Attila József nominatae, Acta Historica 86, 1988, s. 27-30 - cyt. za: S. A. S r o k a, Piastówna, s. 30.

104 S. A. S r o k a, Piastówna, s. 36, przyp. 36, oraz t e n ż e, Чи існувала, s. 271 n. (gdzie informacja o korespondencji z K. Jasińskim); zob. K. J a s i ń s k i, Rodowód Piastów śląskich, s. $517-519$. 
dokumentu, wystawionego przez tegoż władcę po latach (1326): in Rutheniam, quo cum quibusdam baronibus regni nostri fidelibus pro adducenda prima consorte nostra accesseramus $^{105}$. Do zawarcia małżeństwa doszło, zdaniem S. A. Sroki, w 1306 r. ${ }^{106}$ Przemawia za tym, jego zdaniem, kilka przesłanek. Po pierwsze, na ten rok datuje to małżeństwo Jan Długosz. Po drugie, 23 VI 1306 r. Maria już jako królowa węgierska wystawiła dokument i opieczętowała go tylko pieczęcią sygnetową. Wydaje się, że od ślubu upłynęło zbyt mało czasu, aby wykonać dla królowej właściwą pieczęć. Po trzecie, ok. 1305 r. Kazimierz bytomski zaciągnął pożyczkę 140 grzywien groszy, najpewniej na pokrycie kosztów weselnych.

Dlaczego doszło do tego małżeństwa i kto o nim zadecydował? Otóż małżeństwo to umacniało sojusz Władysława Łokietka z Karolem Robertem. Maria była blisko spokrewniona z księciem Władysławem, który był bratem ciotecznym jej ojca ${ }^{107}$. Jeżeli przypuszczenie o ruskim pochodzeniu Heleny, matki Marii, i pobycie tej ostatniej na Rusi jest słuszne, to Marię łączył z Władysławem Łokietkiem jeszcze jeden związek. Mianowicie Maria, przebywając na dworze swojego najbliższego wuja, czyli księcia halicko-włodzimierskiego Jerzego Lwowica, pozostawałaby pod opieką jego żony Eufemii kujawskiej, która była siostrą Łokietka. Ponadto, jak zwracał uwagę K. Jasiński: „Maria, córka Kazimierza i pierwsza żona Karola Roberta, króla Węgier, w wypadku gdyby jej matka Helena była córką Lwa, byłaby prawnuczką Beli IV, umacniającą przez to prawa Karola Roberta do sukcesji po Arpadach"108. Wydaje się, że pewną rolę w zawarciu tego małżeństwa odegrały też względy militarne. W momencie gorących walk z Przemyślidami Karol Robert pozyskiwał w ten sposób dwóch lenników czeskich, Kazimierza bytomskiego i jego brata Bolesława opolskiego; zapewne pozyskałby i ich najstarszego brata, Mieszka cieszyńskiego, gdyby nie przeciwdziałania Wacława III, o których piszę niżej ${ }^{109}$. Było to niezwykle ważne ze względu na kluczowe położenie władztwa Kazimierza bytomskiego dla komunikacji pomiędzy Morawami i Polską, którą książę mógł blokować, a przynajmniej utrudniać. Wydaje się, że wyjaśniliśmy w ten sposób pożytki, jakie płynęły dla Władysława Łokietka i Karola Roberta z zawarcia tego małżeństwa. Nie wiemy, kto był jego pomysłodawcą. Możemy jednak się domyślać, że ważny, a może nawet decydujący, głos w tej sprawie, miał protektor obydwu tych władców, palatyn Amadej. Musimy pamiętać, że w momencie podjęcia decyzji o zawarciu tego małżeństwa panowanie Władysława Łokietka w Polsce czy Karola Roberta na Węgrzech nie były jeszcze przesądzone. O sukcesie Łokietka rozstrzygnął dopiero wiec krakowski 1 IX 1306 r., podczas którego Małopolanie uznali jego władzę. Karol Robert, gdy zapadała decyzja o małżeństwie z Marią, znajdował się w niezwykle trudnym położeniu militarnym. Wyruszał mianowicie po żonę w czasie, kiedy rezultat walk z Sasami spiskimi i koszyczanami nie był jeszcze przesądzony. Dopiero w czasie

${ }^{105}$ Cyt. za: S. A. S ro k a, Piastówna, s. 30, przyp. 9.

106 Tamże, s. 37; te n ż e, Чи існувала, s. 276.

107 Ojciec Kazimierza bytomskiego, Władysław opolski, był rodzonym bratem matki Łokietka, Eufrozyny (K. J a s i ń s k i, Rodowód Piastów śląskich, s. 504-505).

108 Tamże, s. 518.

109 Zob. przyp. 111-112. Nie wiemy, jakie było stanowisko czwartego spośród braci, Przemysła raciborskiego, ale nie miało to większego znaczenia, gdyż zmarł on niebawem 7 V 1306 r. 
tej podróży oddane mu wojska odniosły walne zwycięstwo, chorągiew koszyczan z godłem Przemyślidów zawieziono królowi na Ruś jako trofeum. Wobec ruskich krewnych Marii miał to być najpewniej dowód, że Karol Robert wart jest jej ręki, Nie można wykluczyć, że chodziło o natychmiastowe pozyskanie od nich posiłków. Jest to tym bardziej prawdopodobne, że pomocy takiej nie mógł na pewno udzielić Władysław Łokietek, który sam potrzebował wtedy wsparcia. Ponieważ koszyczanie walczyli pod chorągwią Przemyślidów, a Wacław III zrzekł się korony węgierskiej już w październiku 1305 r. ${ }^{110}$, to można przypuszczać, że Karol Robert udał się po swoją żonę najpóźniej w tym właśnie czasie. Dla datacji tego małżeństwa ważny jest jeszcze jeden aspekt. Otóż - jak wiadomo - król Wacław III poślubił 5 X 1305 r. Wiolę, córkę Mieszka księcia cieszyńskiego ${ }^{111}$, który był starszym bratem Kazimierza księcia bytomskiego. Wydaje się mało prawdopodobne, aby decyzja o ślubie Marii z Karolem Robertem nastąpiła po zawarciu małżeństwa Wacława III z Wiolą. Łatwiej natomiast wyobrazić sobie, iż najpierw zadecydowano o wydaniu Marii za Karola Roberta, a dopiero w reakcji na to Wacław III, chcąc utorować sobie dostęp do Małopolski i Wielkopolski, został skłoniony do zawarcia w pośpiechu tak, wydawałoby się, mało ważnego dlań (i zaskakującego nawet dla współczesnych ${ }^{112}$ ) małżeństwa.

Nawet gdyby nasze przypuszczenia były błędne, to i tak za pewnik możemy przyjąć, że Maria bytomska została żoną Karola Roberta przed 23 VI 1306 r. ${ }^{113}$ S. A. Sroka przyjmuje, że Maria musiała być koronowana na królową Węgier przez ówczesnego biskupa weszpremskiego Benedykta, gdyż koronowanie królowych węgierskich było już od pewnego czasu przywilejem tych hierarchów ${ }^{114}$. Oni zostawali także kanclerzami królowych. Dysponujemy tylko dwiema wzmiankami o kanclerzu królowej Marii (z 1312 oraz 28 IV 1313 r.). Był nim wówczas Stefan z rodu Ákos, który został biskupem weszpremskim w drugiej połowie $1311 \mathrm{r}$. Był on w tym czasie szczególnie zaufanym człowiekiem Karola Roberta, o czym świadczy fakt, że to właśnie Stefanowi i arcybiskupowi ostrzyhomskiemu Tomaszowi monarcha powierzył w 1311 r. najważniejszą, a może też i najtrudniejszą, misję w czasie całego swojego panowania. Chodziło mianowicie o odebranie wpływów Amadejowicom. Stało się to możliwe wobec nagłej zmiany sytuacji na skutek wydarzeń w Koszycach na początku września 1311 r. Znajdujący się u szczytu potęgi Amadej zażądał od króla, aby za dotychczasowe zasługi przekazano mu posiadłości „buntowników”, a w tym przede wszystkim miasto Koszyce ${ }^{115}$. Gdy 5 IX 1311 r. wjeżdżał uroczyście do Koszyc, aby objąć je w posiadanie, doszło do wybuchu gwałtownych rozruchów, w wyniku których palatyn wraz z częścią swej świty poniósł śmierć. Dwóch najstarszych

110 J. Š u sta, Soumrak, s. 675 n.; t e nże, Poslední Přemyslovci, s. 459; K. M a rá z, Václav III., s. 49-50.

${ }^{111}$ K. J a s i ń s k i, Rodowód Piastów śląskich, s. 598-599.

112 K. M a rá z, Václav III., s. 50.

113 Gy. Kris stó, Károly Róbert családja, Aetas 20, 2005, s. 19, w polemice z pracami S. A. Sroki przyjmuje, że Karol Robert poślubił Marię bytomską dopiero w pierwszej połowie $1311 \mathrm{r}$.

114 S. A. S r o k a, Piastówna, s. 39 n. Bliżej o nim zob. też Gy. K r i s tó, Károly Róbert, s. 19 n.

115 O. H a 1 a g a, Počiatky, s. 317 n. 
jego synów, Jan i Dawid, oraz wielu ich towarzyszy zostało uwięzionych ${ }^{116}$. Karol Robert w lot zrozumiał, iż oto nagle stanął przed możliwością przejęcia faktycznej władzy w tym rejonie. Posłał do Koszyc dwóch rozjemców, którymi zostali właśnie arcybiskup ostrzyhomski Tomasz i biskup weszpremski Stefan (będący zarazem, co odnotowują przekazy dotyczące ugody, kanclerzem królowej) ${ }^{117}$. Było to niebywałe posunięcie, gdyż koszyczanie zabili najbliższego stronnika króla, a ten nie tylko ich za to nie ukarał, lecz wystąpił z ,buntownikami” jako jedna strona sporu. Podyktowana 3 X 1311 r. przez wysłanników królewskich ugoda sprowadzała się do całkowitej kapitulacji Amadejowiców, którzy zostali zmuszeni do oddania wszystkich regaliów i innych dóbr pozyskanych nieprawnie przez Amadeja, a ponadto musieli się pogodzić z całkowitą bezkarnością koszyczan za zamordowanie Amadeja i części jego świty ${ }^{118}$.

Gdy dwaj najstarsi synowie Amadeja zostali po oddaniu zakładników uwolnieni i gdy całe stronnictwo Amadeja otrząsnęło się z pierwszego szoku wywołanego śmiercią palatyna, Amadejowice rozpoczęli gorączkowe przygotowania do rozprawy z Karolem Robertem. Na gwałt poszukiwali sprzymierzeńców. Udało im się uzyskać pomoc Mateusza Csáka (1700 zbrojnych) ${ }^{119}$, który w czasie walk o tron węgierski wywalczył sobie w północno-zachodnich Węgrzech pozycję równą niemal Amadejowi. Do wielkiej bitwy pomiędzy wojskami Amadejowiców i ich sprzymierzeńców z siłami królewskimi doszło 15 VI 1312 r. pod Rozgony (obecnie Rozhanovce), ok. $10 \mathrm{~km}$ na wschód od Koszyc. Wojska Karola Roberta odniosły - po ciężkich walkach - wielkie zwycięstwo, do którego przyczynili się walnie mieszczanie koszyccy oraz Sasi spiscy ${ }^{120}$.

116 Tamże, s. 333; A. Z s o 1 d o s, Kassa túzsai (Pillanatfelvétel 1311-ből Aba Amadé famíliájáról), Történelmi Szemle 39, 1997, nr 3-4, s. 345-362; t e n ż e, King and oligarchs in Hungary at the turn of the thirteenth and fourteenth centuries, Hungarian Historical Review 2, 2013, nr 2, s. 221; F. U 1 i č n ý, Vývoj politických vzt’ahov v Uhorskom král'ovstve, najmä na východnom Slovensku, v prvej polovici 14. storočia, w: Bitka pri Rozhanovciach (jak w przyp. 53), s. $15 \mathrm{n}$.

117 Codex diplomaticus Hungariae, t. VIII, cz. 1 (1832), nr 192: Nos Martinus Dei gracia episcopus Agriensis significamus, - - quod nobilis domina, relicta Omodaei palatini bonae mem(oriae), Ioannes, Nicolaus, Dauid, et Ladislaus magistri, filii eiusdem, suo et suo et Omodei ac Dominici fratrum suorum nomine, item magister Donch, Ioannes filius Georgii Sinke, Aegidius Bagly, Ricolphus filius Ricolphi--coram nobis personaliter constituti, m. Dionysium, filium Bodon et Ioannem filium Poch praesentes et consentientes fecerunt, statuerunt et ordinauerunt suos procuratores legitimos et nuncios speciales ad impetrandum, ad significandum et seriatim enarrandum coram capitulo Agriensi compositionem factam mediantibus ven. in Ch. PP. d. Thoma, Dei gracia archiepiscopo Strigoniensis eiusdemque loci C. perpetuo et Stephano per eamdem episcopo Vesprimiensi, aulae d(ominae) reginae cancellario, per dictum d(ominum) nostrum Karolum Dei gracia regem Hungariae ad id specialiter destinatis, inter d(ominum) regem et ciues de Cassa ex vna parte et inter praedictam dominam relictam Omodaei palatini et filios eiusdem memoratos ex altera.

118 Dokument wielokrotnie drukowany, wraz z tłumaczeniem słowackim wydał go O. H a l a g a, Počiatky, s. 325 n.

119 Tamże, s. 335.

120 Szczegółowy opis bitwy dał te n że, Počiatky, s. 347 n. Zob. też Gy. K r i s tó, A rozgonyi csata, Budapest 1978; A. Z s o 1 d o s, King, s. 229 n., a przede wszystkim zbiór wydany z okazji 700-lecia bitwy: Bitka pri Rozhanovciach (jak w przyp. 53), gdzie F. U l i č ný, Vývoj, s. 18, przyp. 33, podaje starszą literaturę. 
W świetle tych wydarzeń i wiedzy o znaczeniu handlu miedzią możemy nieco inaczej spojrzeć na rozgrywający się jednocześnie w Krakowie bunt wójta Alberta. Wszelkie dywagacje o podłożu tego wystąpienia, rzekomo mającego wynikać ze związków Krakowa z Czechami, są pozbawione podstaw. Historycy, którzy głosili tezę o przewadze handlu równoleżnikowego (Niemcy/Czechy-Wrocław-Kraków-Ruś) nad handlem południkowym (Koszyce-Kraków-Toruń-Gdańsk-Flandria) w życiu gospodarczym Krakowa, nie byli po prostu zorientowani w materiale źródłowym. Gospodarcza egzystencja Krakowa, jak pamiętamy, nazywanego przez hanzeatów Kupferhaus, opierała się na handlu miedzią. Gdy zatem w Małopolsce w 1304 r. zjawił się Władysław Łokietek jako sojusznik czy wysłannik Amadeja, pod którego kontrolą pozostawały wszystkie złoża miedzi i drogi do Koszyc, mieszczanie krakowscy nie mieli innego wyboru niż podporządkowanie się nowemu księciu. Jak wiadomo, nie nastąpiło to natychmiast i zapewne nie bez negocjacji, na co wskazuje „miedziowy” dokument z 12 IX 1306 r., ale nie ulega wątpliwości, że krakowianie byli w bardzo trudnej sytuacji. Opanowanie lub podporządkowanie przez Łokietka ziemi sieradzkiej i łęczyckiej oraz Kujaw i Pomorza Gdańskiego dodatkowo uzależniało ich od księcia. Było oczywiste, że w tej sytuacji miasto musi podporządkować się Łokietkowi, co jak wiemy - nastąpiło 1 IX 1306 r. Potem krakowianie nie mieli w zasadzie żadnej możliwości, aby występować przeciwko temu władcy, gdyż groziło to poważnymi konsekwencjami. Mimo że szlak handlowy przynosił Władysławowi Łokietkowi duże dochody, to jednak ciągle brakowało mu pieniędzy ${ }^{121}$. Najpewniejszym źródłem ich pozyskania był niewątpliwie niezdolny do oporu Kraków, który polski władca mógł bezkarnie obciążać najróżniejszymi opłatami. Sytuację mieszczan trafnie przedstawiał Jan Długosz, piszący, że książę „,gnębił ich podatkami i ciężkimi świadczeniami na prowadzenie wojen, które mu wypowiedziano"122. Poglądu tego nie spotykamy w żadnych innych wcześniejszych źródłach; nie można nawet wykluczyć, iż zdanie to jest jedynie przypuszczeniem kronikarza. Gdyby nawet tak było, to należy uznać je za bardzo trafne. Godzącą w interesy handlu politykę fiskalną i monetarną Łokietka, obniżającego dla łatwego zysku zawartość srebra w wybijanym pieniądzu, potwierdzają badania Borysa Paszkiewicza ${ }^{123}$.

Dlaczego jednak doszło do buntu krakowian? Otóż nawet utrata kontroli nad Pomorzem Gdańskim przez Łokietka nie zmieniała w niczym ich zależności od tego władcy. Mieszczanie zdawali sobie sprawę, że Amadej, sojusznik księcia polskiego na Węgrzech, zwyciężywszy koszyczan i Sasów, przejął zupełną kontrolę nad handlem miedzią. Jednakże sytuacja całkowicie się zmieniła, gdy 5 IX 1311 r. palatyn został zabity przez koszyczan, których nieoczekiwanie wsparł król Karol Robert. Dopiero te dwa wydarzenia otworzyły przed krakowianami możliwość wystąpienia przeciwko Władysławowi Łokietkowi, który „gnębił ich podatkami i ciężkimi świadczeniami”.

${ }^{121}$ Zob. np. spostrzeżenia J. J u d z i ń s k i e g o, Układy polsko-krzyżackie z 1309 roku w sprawie zwrotu Pomorza Gdańskiego, Komunikaty Mazursko-Warmińskie 1994, nr 2-3, s. 147 , przyp. 7.

122 Joannis Dlugossii Annales, lib. IX, s. 82; thum. pol.: Jana Długosza Roczniki, ks. IX, s. 101.

${ }^{123}$ B. P a s z k i e w i c z, Mennictwo Władysława Łokietka, Wiadomość Numizmatyczne 30, 1986, z. 1-2 (115-116), s. 84-85. 
Kraków tę możliwość natychmiast wykorzystał. Ponieważ w starszej literaturze krążą różne przypuszczenia na temat początków buntu wójta Alberta, przyjrzyjmy się na chwilę tej kwestii. Przyjmowano, że początek buntu mieszczan krakowskich przypadał na maj $1311 \mathrm{r} .{ }^{124}$ Jak sądził Edmund Długopolski, świadczyć miało o tym niewybranie 17 V 1311 r. Piotra Guisa na stanowisko wójta sądowego; funkcji tej nie należy mylić z dziedzicznymi wójtami, którymi byli wtedy Albert i jego brat Henryk. Ów Piotr Guis przez co najmniej 11 lat sprawował wcześniej obowiązki wójta sądowego. Niewybranie jakiegoś urzędnika nie musi jednak oznaczać jeszcze buntu. Data majowa była E. Długopolskiemu potrzebna, aby uzyskać powiązanie buntu z ówczesnym pobytem króla czeskiego Jana Luksemburskiego na Morawach. Spiskowanie krakowian z Czechami w maju 1311 r. byłoby z punktu widzenia ich zaangażowania $\mathrm{w}$ handel miedzią zupełnym szaleństwem. Pogląd o inspiracji Jana Luksemburskiego w wywołaniu buntu krakowskiego został wprawdzie dość powszechnie przyjęty ${ }^{125}$, ale najnowsze badania go kwestionują. Robert Antonín wykazał ponad wszelką wątpliwość, iż nowy król Czech nie pozostawał w żadnym związku ze zbuntowanym przeciwko Władysławowi Łokietkowi mieszczaństwem krakowskim. Jak pisze czeski historyk, Jan „nie podjął żadnych kroków w celu interwencji w Krakowie ani nigdzie indziej na ziemiach polskich. Nie miał na to ani czasu, ani wystarczających środków. Jego polityka w tym okresie podporządkowana była przede wszystkim pilnej potrzebie zakończenia buntu szlachty w kraju, zwłaszcza na Morawach, ale przede wszystkim konieczności podporządkowania sobie wrogiego mu Mikołaja II, księcia opawskiego" ${ }^{126}$. Z poglądem o wybuchu buntu już w maju 1311 r. nie zgadzał się też Jerzy Wyrozumski, który w następujących słowach ustosunkował się do tej kwestii: „Sytuacja mogła być i na pewno była już wówczas napięta, a podstawy polityczne spolaryzowane, ale nic nie wskazuje na to, aby już w maju 1311 r. miasto wypowiedziało Lokietkowi posłuszeństwo, bo tylko taki stan można by uważać za bunt. Ostrożność nakazuje przyjąć, że o otwartym buncie możemy mówić na jakiś nie dający się ściśle określić czas przed 21 grudnia 1311 r., kiedy to Władysław Łokietek zastosował represje w stosunku do niektórych mieszczan krakowskich. Pewną wskazówkę chronologiczną w tym zakresie znajdujemy w dokumencie Władysława Łokietka z 31 października 1311 r., mocą którego Łokietek przekazał wójtostwo sandomierskie Rupertowi i Markowi, synom byłego wójta sandomierskiego Marka. Wójtostwo to zostało właśnie przez tego władcę odebrane ostatnim wójtom Witkowi i Zygfrydowi za to, że dopuścili się »zdrady, przestępstwa i zbrodni obrazy monarszego majestatu «"127. W pełni zgadzając się

${ }^{124}$ E. Dług o p o $1 \mathrm{ski}$, Bunt, s. 9.

125 Np. J. Š u s t a, Počátky lucemburské 1308-1320 (Dvě knihy českých dějin II), wyd. 2, Praha 1926, s. 148-151; t e n ż e, Král cizinec (České dějiny, t. II, cz. 2), Praha 1939, s. 167-169.

${ }^{126}$ R. A n to n ín, Działalność polityczna Jana Luksemburskiego w okresie buntu krakowskiego wójta Alberta i jego ocena w czeskiej historiografii, w: Bunt wójta Alberta (jak w przyp. 101), s. 18. Podobnie już B. N o w a c ki, Czeskie roszczenia do korony w Polsce w latach 1290-1335, Poznań 1987, s. 89 n.; T. P i e tr a s, „Krwawy wilk z pastorałem”. Biskup krakowski Jan zwany Muskatą, Warszawa 2001, s. 106-107; T. J u r e k, Polska droga, s. 182. Charakterystyczne, że ostatni biograf Jana, J. S p ě vá č e k, Jan Lucemburský a jeho doba 1296-1346, Praha 1994, nie podniósł w ogóle sprawy jego związków z buntem krakowskim.

127 J. Wy r o z u m s k i, Dzieje Krakowa, t. 1, s. 207-208. 
z tym rozumowaniem, możemy stwierdzić, że bunt wójta Alberta wybuchł przed 21 XII 1311 r. Jest to terminus ad quem, jako datę post quam - co wynika już z naszych rozważań - możemy przyjąć datę śmierci Amadeja 5 X 1311 r. Nie da się rozstrzygnąć, czy bunt wybuchł bliżej września czy grudnia. J. Wyrozumski wskazuje na dokument Władysława Łokietka z 31 X 1311 r., w którym książę nadał Rupertowi i Markowi wójtostwo sandomierskie, odebrane Witkowi i Zygfrydowi - musieli oni dopuścić się wrogich wobec władcy czynów, może buntu, ale - wszystko na to wskazuje - sytuacja była już opanowana. Czy do tych czynów ośmieliła Witka i Zygfryda zmiana sytuacji na Węgrzech po śmierci Amadeja, tego nie wiemy. Z dokumentów wynika, że kupcy sandomierscy uczestniczyli w handlu z Węgrami ${ }^{128}$, możliwe zatem, że też zbuntowali się przeciwko Łokietkowi. Nie znaczy to jednak, że już wówczas wybuchł też bunt krakowski. Wydaje się, że Łokietek nie zwlekał z ukaraniem mieszczan krakowskich i można przypuszczać, że dokument z 21 XII 1311 r. wystawiony został w stosunkowo krótkim czasie po wybuchu buntu i zapewne po jakichś krótkich rokowaniach, które skończyły się niepowodzeniem.

Zwracano często uwagę na współuczestnictwo w buncie także bożogrobców z Miechowa. Trudno jednak dowieść, iż konflikt Władysława Łokietka z tym klasztorem miał coś wspólnego z wystąpieniem krakowskim. Przypuszczenie takie opiera się jedynie na zbieżności czasowej. Mianowicie 12 X 1312 r. papież Klemens V zwrócił się do arcybiskupa gnieźnieńskiego, aby nie pozwolił na ciemiężenie bożogrobców przez „rabusiów, grabieżców i najeźdźców”"129. „Wolno się tylko domyślać - pisał J. Wyrozumski - że chodzi tu o ludzi Łokietka"130. Nie mamy jednak na to żadnego dowodu. Najpewniej stosunki bożogrobców miechowskich z Łokietkiem układały się jak najgorzej od czasu powrotu księcia w 1304 r. Mogło się do tego przyczynić darowanie przez Łokietka w 1304 r. służącemu mu rycerzowi węgierskiemu Piotrowi z Dronowa wsi Chmielów w komitacie Sáros, należącej do miechowitów. Nadanie to zostało powtórzone w 1305 r., co wskazuje, że z jego realizacją był jakiś kłopot. Ostatecznie bożogrobcy utrzymali te dobra, a w końcu w 1313 r. zamienili je na Lendak; tam przebywał na wygnaniu po buncie prepozyt Henryk ${ }^{131}$. Do szczególnego zaostrzenia konfliktu dojść musiało w 1311 r., kiedy to w Roczniku miechowskim zanotowano: ecclesia Mechoviensis incastellata est per Iohannem filium Budivogii ${ }^{132}$. Chociaż konflikt Władysława Łokietka z bożogrobcami wiązał się w jakiś sposób ze sprawami węgierskimi, to jednak nie byli oni kupcami i nie zajmowali się handlem miedzią, a więc spór ten miał inne uwarunkowania niż zatarg księcia z Krakowem ${ }^{133}$.

${ }^{128}$ W 1310 r. Bolesław II mazowiecki, udzielając kupcom zezwolenia przejazdu przez swoje księstwo, wymienia jako adresata swojego przywileju Kraków, Sandomierz oraz pozostałe miasta terre Cracouiensis et Vngarie (Nowy kodeks dyplomatyczny Mazowsza, t. II, nr 123).

129 Kodeks dyplomatyczny Małopolski, wyd. F. Piekosiński, t. II, Kraków 1886, nr 554.

130 J. W y r o z u m s k i, Dzieje Krakowa, t. I, s. 209. Z kolei Z. P ę c k o w s k i, Miechów. Studia z dziejów miasta i Ziemi Miechowskiej do roku 1914, Kraków 1967, s. 50-53, uważał za oczywisty fakt, że bożogrobcy spiskowali z Janem Luksemburskim i uczestniczyli w buncie.

131 Słownik historyczno-geograficzny województwa krakowskiego w średniowieczu, cz. I-V, Wrocław 1980 - Kraków 2016, tu cz. IV, s. 394-395.

132 Z. B u d k ow a, Rocznik miechowski, s. 124.

133 Jan Długosz podaje (Annales, lib. IX, s. 87), że prepozyt Henryk był bratem rodzonym wójta Alberta; jest to jednak pomyłka, gdyż wójt Albert rzeczywiście miał brata Henryka, 
Sprawa ta nie może zatem służyć do wyznaczenia daty wybuchu buntu krakowskiego. Ostatecznie zatem przyjmujemy, iż datami skrajnymi dla wybuchu buntu wójta Alberta pozostają: śmierć Amadeja 5 X 1311 i wystawienie dokumentu konfiskacyjnego Łokietka 21 XII $1311 \mathrm{r}$.

Istotnym elementem buntu wójta Alberta było przybycie do Krakowa księcia Bolka opolskiego i przejęcie przez niego władzy w mieście, przy czym nie udało mu się opanować zamku wawelskiego. Wcześniej w historiografii traktowano go jako wysłannika, czy nawet starostę, króla czeskiego Jana Luksemburskiego ${ }^{134}$. Pogląd ten w świetle cytowanych badań R. Antonína i zmiany datacji dokumentu, w którym występuje Bolko jako starosta (pochodzi on w istocie z 1292 r.), jest całkowicie pozbawiony racji ${ }^{135}$. Kto zatem skłonił Bolka do poparcia buntu mieszczan krakowskich i otwartego wystąpienia przeciwko Władysławowi Łokietkowi? Aby tę kwestię wyjaśnić, przyjrzyjmy się okresowi pobytu księcia opolskiego w Krakowie. Otóż Rocznik małopolski informuje, że książę opuścił Kraków zaledwie po dwóch miesiącach: mox post duos menses advocatum et pociores cives cepit et civitatem duci Wladislao vendidit et tradidit per fraudem ${ }^{136}$. Już Franciszek Piekosiński i Józef Szujski zauważyli, że książę opolski musiał opuścić Kraków pomiędzy $5 \mathrm{~V}$ a 14 VI 1312 r. ${ }^{137}$ W księgach miejskich zanotowano w 1312 r. dwukrotnie wybór rady, najpierw 5 maja, a następnie 14 czerwca. Pierwsza rada składała się jeszcze $\mathrm{z}$ buntowników, druga została wybrana po przejęciu miasta przez Łokietka, o czym informuje wyraźnie odnośna zapiska ${ }^{138}$. Z ustaleniem tym zgodzili się późniejsi badacze, m.in. Edmund Długopolski oraz Jerzy Wyrozumski, który dodał: „Należy przypuszczać, że Łokietek zatroszczył się o rychłe obsadzenie stanowisk miejskich, zatem czas przybycia Bolka do Krakowa przypadłby na początek kwietnia lub co najwyżej na koniec marca" 139 .

Wiele wskazuje na to, że termin pobytu Bolka opolskiego w Krakowie nie był przypadkowy. Przyjrzyjmy się sytuacji na Węgrzech i stosunkom polsko-węgierskim w tym czasie. Otóż okres od kwietnia do początku czerwca 1312 r. upływał na gorączkowych przygotowaniach do frontalnego starcia pomiędzy stronnictwem królewskim, wspieranym przez koszyczan i Sasów spiskich, oraz stronnictwem przeciwnym - synami Amadeja i Mateuszem Csákiem ${ }^{140}$. Konflikt ten, jak pamiętamy, rozstrzygnęła bitwa stoczona 15 VI 1312 r. Zanim do tego doszło, obydwa

mieszczanina krakowskiego, którego nie można mylić z prepozytem (J. Wy ro z u m s k i, Dzieje Krakowa, t. I, s. 204).

134 Szerzej zob. A. Gra b ow s ka, Bunt, s. 19-31.

135 T. N ow a k ow s ki, Małopolska elita władzy wobec rywalizacji o tron krakowski w latach 1288-1306, Bydgoszcz 1992, s. 65-70.

${ }^{136}$ Monumenta Poloniae historica, t. III, s. 188.

137 Najstarsze księgi i rachunki miasta Krakowa, s. 25, przyp. 2.

138 Tamże, s. 25: In den iaren Gotis tusent driehundirt vnde in deme zweltftem iare worden dise ratheren gecorne an deme vritage in der Crucevoychen [5 V 1312], a niżej: In deme selben iare, do di stat Cracoue vider wart vnserem heren herchogen Wladizlauen gegeben von deme herchogen von Opulle, dar nach sente Vites abent, an eynme mittevoychen [14 VI] vrden dise ratheren gecorn.

139 E. D ł u g o p o 1 s k i, Bunt, s. 25 n.; J. Wy r o z u m s k i, Dzieje Krakowa, t. I, s. 209.

${ }_{140}$ O. H a l a g a, Počiatky, s. 331 n. 
stronnictwa musiały zastanawiać się, jak zachowa się Władysław Łokietek. Synowie Amadeja zabiegali niewątpliwie, aby ich dawny protegowany i sojusznik, za którego ich ludzie „codziennie walczyli” i ,przelewali własną krew”, wsparł ich teraz w dramatycznym momencie. Łokietek najpewniej obiecał im wsparcie. Sytuację skomplikował wybuch buntu w Krakowie, a wcześniej już może w Sandomierzu. Jaka była zaś strategia króla Karola Roberta i jego stronników? Z pewnością dążyli oni, aby uniemożliwić Łokietkowi przyjście z pomocą Amadejowicom. Bunt krakowian był zatem dla Karola Roberta jakby „darem z niebios”. Nie można wykluczyć, że w wywołaniu tego buntu odegrali jakąś rolę mieszczanie koszyccy. Nie mamy na to żadnego dowodu, ale być może sam upadek Amadeja nie wystarczył, aby skłonić krakowian do buntu, może potrzebne były dodatkowe zachęty ze strony koszyczan, którzy mogli powoływać się na przychylność i wsparcie młodego króla węgierskiego. Są to jednak tylko przypuszczenia.

Wraz z wybuchem buntu wójta Alberta zapewne rosła nadzieja młodego króla, że uda się wewnętrznymi konfliktami zatrzymać Władysława Łokietka w Polsce. Z upływem kolejnych miesięcy zauważono jednak, że bunt krakowian nie okazał się śmiertelnym zagrożeniem dla polskiego księcia. Wawel nie został zdobyty; najpewniej jego załoga trzymała miasto w klinczu; sandomierzanie, o ile w ogóle doszło tam do buntu, zostali przez Łokietka szybko spacyfikowani. W takich okolicznościach stronnictwo Karola Roberta mogło się obawiać, że wojska Łokietka, mimo kryzysowej sytuacji w Małopolsce, ruszą jednak na pomoc Amadejowicom. O tym, że Karol Robert mógł czuć się zagrożony ze strony Łokietka, świadczy fakt, iż główne walki pomiędzy buntownikami (tj. Amadejowicami i ich koalicjantami) a Karolem Robertem, w okresie krótko poprzedzającym bitwę pod Rozgony, toczyły się wokół Zamku Szaryskiego, który kontrolował drogi biegnące do Małopolski. Stronnicy Mateusza Csáka i Amadejowiców obsadzili tę potężną twierdzę już w kwietniu 1312 r. Karol Robert uznał opanowanie Zamku Szaryskiego przez swoich wrogów za szczególnie niebezpieczne i osobiście wyprawił się z wojskiem przeciwko jego załodze $^{141}$. Oblegał go stosunkowo długo, z całą pewnością od 9 do 29 V 1312 r., a być może i dłużej ${ }^{142}$. Utrzymanie tego zamku, kontrolującego drogę do Małopolski, było bardzo ważne dla buntowników; stąd można było „szachować” kupców koszyckich transportujących miedź do Małopolski oraz oczekiwać na pomoc z Polski. Buntownicy za wszelką cenę starali się utrzymać w swoich rękach zamek i dlatego główne siły Mateusza Csáka, 1700 kopijników, które przybyły na pomoc Amadejowicom, skierowano najpierw przeciwko królowi, aby go odeprzeć spod Zamku Szaryskiego. Karol Robert na wiadomość o zbliżających się kopijnikach Csáka, dał za wygraną i odstąpił od oblężenia ${ }^{143}$. Wówczas buntownicy ruszyli na Koszyce.

$\mathrm{Na}$ istnienie w 1312 r. sojuszu pomiędzy Władysławem Łokietkiem a Amadejowicami wskazują też ci uczeni, którzy badali losy Amadejowiców i ich sojuszników

${ }^{141}$ Karol Robert często wynagradzał potem zasługi swoich wiernych poddanych, którzy odznaczyli się męstwem w oblężeniu Zamku Szaryskiego (np. Regesta diplomatica nec non epistolaria Slovaciae, t. I-II, wyd. V. Sedlák, Bratislavae 1980-1987, tu t. I, nr 1011).

${ }^{142}$ F. U li čný, Vývoj, s. 17, gdzie opisane też wcześniejsze ataki Amadejowiców na Sárospatak oraz Sečovce.

${ }_{143}$ Tamże. 
po bitwie pod Rozgony. W 1912 r., niezależnie od siebie, zarówno Władysław Semkowicz, jak i Jan Dąbrowski, stwierdzili, iż niedobitki Amadejowiców po bitwie schroniły się w Polsce ${ }^{144}$. W. Semkowicz tak wówczas pisał: „Wtedy to niewątpliwie synowie Amadeja oraz inni członkowie rodu Aba, którzy ocaleli pod Rozgonyem, uszli przed zemstą króla do Polski, gdzie znaleźli schronienie i chętne przyjęcie u Władysława Łokietka, pomnego dawnych usług i zasług ich ojca"145. Obydwaj badacze zwrócili też uwagę na niezwykle ciekawy dokument Karola Roberta z 28 X 1323 r., w którym król - na prośbę Władysława Łokietka - przywracał do łask Tomasza i Mikołaja, synów Stefana Csirke i zwracał im dawne posiadłości ${ }^{146}$. Na ten sam dokument powoływali się też uczeni słowaccy Branislav Varsik i Ferdinand Uličný, którzy przyjmowali, iż po bitwie Amadejowice schronili się w Polsce ${ }^{147}$. F. Uličný zwracał jednak uwagę, że w dokumencie tym brak informacji, iż rodowcy Csirke uciekli do Polski akurat po bitwie pod Rozgony jako sprzymierzeńcy Amadejowiców. Według F. Uličnego ich ucieczka do Polski mogła być motywowana innymi względami ${ }^{148}$. Trudno jednak z tym ostatnim poglądem się zgodzić, gdyż w dokumencie czytamy, że uciekli oni do Polski z powodu popełnienia ,jawnych zbrodni” (pro manifestis eorum sceleribus). Dokument ponadto informuje, że dobra rodowców Csirke dzierżył do 1323 r. palatyn Filip (Druget), który - jak wiemy - otrzymał wiele dóbr po Amadejowicach i ich sprzymierzeńcach właśnie za zasługi po bitwie pod Rozgony ${ }^{149}$. Wydaje się też mało prawdopodobne, aby Władysław Łokietek ujął się za jakimiś zwykłymi węgierskimi buntownikami, gdyby nie chodziło w danym wypadku o ludzi szczególnie dla niego zasłużonych. O tym, że niedobitki Amadejowiców schroniły się w Polsce, świadczą też dalsze losy tego rodu ${ }^{150}$. Trzeba także

${ }^{144}$ W. S e m k o w i c z, O pochodzeniu i rozsiedleniu rodu Amadejów w Polsce, Miesięcznik Heraldyczny 5, 1912, nr 9-10, s. 139 n.; J. D ą b r o w s k i, Pochodzenie rodu Amadejów, Przegląd Polski 46, maj 1912, s. 178 n.

${ }_{145}$ W. S e m k ow i c z, O pochodzeniu, s. 141.

146 Tamże, s 141; J. D ą b r o w s k i, Pochodzenie, s. 194; zob. Anjoukori okmánytár. Codex diplomaticus Hungaricus Andegavensis, wyd. I. Nagy, t. II, Budapest 1881, nr 86: Nos Karolus . rex . . significamus . . universis, quod licet possessiones Thome et Nicolai filiorum Stephani dicti Chyurke Idaa et Pali nominate cum suis pertinenciis universis prout eedem ipsos contingebant pro manifestis eorum sceleribus - - ab ipsis alienate et ad manus Philippi palatini fuissent devolute, tandem tamen quia excellentissimus princeps dominus Ladizlaus . . rex Polonie socer noster reverendus, in cuius regnum iidem querentes subterfugia fugitive recesserant et ibidem exules residebant, nos et dominam reginam consortem nostram filiam videlicet suam unacum illustri regina sua consorte karissima honoranda socru nostra diligente postulavit, ut eiusdem Thome et Nicolao demerita ipsorum ignoscere ipsasque eorum possessiones ab ipsis alienatas restitui facere et in nostram regiam graciam eosdem recipere ex regia benignitate dignaremur; regest: Regesta Slovaciae, t. II, nr 1066; Anjou-kori oklevéltár. Documenta res historicas tempore regum Andegavensium illustrantia, t. VII, Budapest-Szeged 1991, nr 536.

${ }_{147}$ F. U 1 i č ný, Vývoj, s. 27: „V krutej vojenskej bitke na poli pri Rozhanovciach 15. júna 1312 Omodejovci, hoci podporovaní vojskom Matúša Čáka Trenčianskeho, prehrali. V boji padli a zomreli aj bratia Ján a Ladislav, synovia nebohého palatína Omodeja. Zostávajúci štyria synovia Omodeja, teda Mikuláš, Dávid, Omodej a Dominik bitku prežili. Nevedno, kde sa hned' po bitke pred král'om ukrývali a zdržiavali. Pravdepodobne zakrátko emigrovali do Pol'ska".

148 Tamże, s. 27, przyp. 97.

149 Tamże, s. $20 \mathrm{n}$.

${ }^{150}$ W. S e m k o w i c z, O pochodzeniu, s. 139 n.; J. Dąbrowski, Pochodzenie, s. 178 n. 
zaznaczyć, iż wsparcie przez Władysława Łokietka w 1312 r. Amadejowiców nie było z jego strony wywołane tylko poczuciem wdzięczności za wcześniejszą pomoc, ale wynikało też ze wspólnoty interesów. Gdyby Amadejowice odnieśli zwycięstwo i przywrócili kontrolę nad węgierskim odcinkiem miedzianego szlaku handlowego, wówczas Władysław Łokietek nie miałby większych trudności z pacyfikacją buntu mieszczan krakowskich. Tym ostatnim groziłby bowiem zakaz wjazdu na Węgry.

Pewne przesłanki wskazują, że to Karol Robert, a najpewniej jego doradcy, przyczynili się do skłonienia Bolka opolskiego do przybycia do Krakowa w końcu marca lub, co bardziej prawdopodobne, na początku kwietnia 1312 r. Czy mamy jakiś dowód na kontakty stronnictwa królewskiego na Węgrzech z Bolkiem opolskim? Pewne fakty wskazują na to, że do takich kontaktów doszło krótko po 10 III 1312 r. Tego dnia zmarł bowiem Kazimierz bytomski, ojciec królowej węgierskiej, teść Karola Roberta, a brat Bolka opolskiego. Z Bytomia musieli udać się na Węgry posłowie, aby zawiadomić parę królewską o śmierci księcia i o terminie jego pogrzebu. Możemy przypuszczać, że ze względu na napiętą sytuację polityczną na Węgrzech Karol Robert pozostał w kraju; pewnie również Maria nie zdecydowała się, aby przybyć na pogrzeb ojca. Z pewnością jednak jakieś poselstwo węgierskie przybyło do Bytomia, a sprawę tę - ze względu na zajmowane stanowisko - musiał omawiać kanclerz królowej, Stefan biskup weszpremski, człowiek świetnie zorientowany w rozgrywkach z Amadejowicami - to on, przypomnijmy, był jednym z głównych ich pogromców na niwie dyplomatycznej, jako współtwórca ugody 3 X $1311 \mathrm{r}$. Teraz jego dokonania sprzed kilku miesięcy mogły zostać obrócone w niwecz. To jednak zapewne za jego sprawą król Karol Robert wysłał na pogrzeb swojego posła, który w czasie uroczystości pogrzebowych w Bytomiu skłonił księcia Bolka opolskiego do wyruszenia na Kraków. Zauważmy, że kilka miesięcy po bitwie pod Rozgony biskup Stefan otrzymał za zasługi od króla duże nadanie. Czy była to nagroda za ugodę z 3 X 1311 r., czy także za działania, które uniemożliwiły Łokietkowi przyjście z pomocą jego sojusznikom - nie wiemy. Książę opolski Bolko, jak zresztą wykazały to jego ostatnie dni pobytu w Krakowie, był władcą rozsądnym i wątpliwe, aby do podjęcia tak ryzykownych kroków nakłoniły go same namowy krakowian; więcej znaczyły namowy i obietnice króla węgierskiego. Gdyby Bolko nie opuścił Krakowa na kilka dni przed bitwą pod Rozgony, być może doczekałby się zresztą wsparcia węgierskiego, które mogło całkowicie zmienić sytuację w Małopolsce. Być może nawet pomoc taka nadeszła; w wykazie cudów dołączonym do Żywotu św. Kingi czytamy o jakimś transitus Ungarorum w rejonie Nowego Sącza, który uniemożliwił mieszczaninowi nowosądeckiemu i jego żonie dotrzeć ad limina sancte domine, aby podziękować za zdziałany cud, czego dopełnili jednak po 8 dniach, feria sexta post diem beati Iacobi apostoli, co wydawcy rozwiązali jako 30 VII 1311 r. ${ }^{151}$ W źródle nie ma jednak daty rocznej, a z kolejności chronologicznie narastających zapisów wynika, że musi tam chodzić o 1310 r.: później dopiero mamy zapis o cudzie zdziałanym w okolicy św. Jana (24 VI) 1311. Oczywiście pojawienie się wojsk węgierskich w Małopolsce w 1310 r. jest mało prawdopodobne. Natomiast wszystkie oddziały

${ }^{151}$ Vita et miracula sanctae Kyngae ducissae Cracoviensis, wyd. W. Kętrzyński, Monumenta Poloniae historica, t. IV (1884), s. 736. 
węgierskie, które pojawiłyby się w Małopolsce po 5 IX 1311 a przed końcem lata 1312 r., musiałyby być przysłane przez Karola Roberta na pomoc buntownikom przeciwko Łokietkowi. To jednak tylko domysły, gdyż nie możemy wykluczyć, iż ów transitus Ungarorum to np. wspomniane niedobitki Amadejowiców, którzy szukali schronienia w Polsce po bitwie pod Rozgony. Najpewniej nigdy nie poznamy wszystkich tajników polityki węgierskiej dotyczącej spraw polskich z okresu od 5 IX 1311 do 15 VI 1312 r.

Podsumowując tę kwestię: nie mamy wprawdzie dowodów, iż Bolko opolski wkroczył do Krakowa za namową Karola Roberta, aby uniemożliwić Władysławowi Łokietkowi przyjście z pomocą Amadejowicom, pewne jest jednak, że bunt wójta Alberta i interwencja księcia opolskiego w Krakowie były niezwykle na rękę królowi węgierskiemu, gdyż utrudniały lub nawet uniemożliwiały Łokietkowi wysłanie posiłków na Węgry.

\section{ZAKOŃCZENIE}

W podsumowaniu całej przedstawionej problematyki należy stwierdzić, że handel miedzią węgierską odegrał ważną rolę w wydarzeniach politycznych i społecznych w Polsce na początku XIV w. Powrót Władysława Łokietka do kraju w 1304 r. oraz opanowanie przez niego Małopolski, ziem sieradzkiej i łęczyckiej, Kujaw i Pomorza Gdańskiego stają się bardziej zrozumiałe, gdy uświadomimy sobie międzynarodowe znaczenie tego handlu. Poważnym błędem w badaniach nad dziejami politycznymi władztwa Władysława Łokietka w latach 1304-1312 było niedocenianie sytuacji politycznej i gospodarczej na Węgrzech. Wszystko wskazuje zaś, że wydarzenia, które rozegrały się tam w latach 1311-1312, są kluczowe dla zrozumienia przyczyn wybuchu buntu wójta Alberta i jego przebiegu.

$\mathrm{Na}$ marginesie badań nad handlem miedzianym coraz wyraźniej rysuje się ogromne znaczenie włączenia się w tę działalność kupców westfalskich. Chociaż byli oni obecni na tym terenie wcześniej, m.in. w Elblągu, a także w Krakowie, to osiedlenie się ich w Starym Mieście Toruniu w 1304/1305 r. zapoczątkowało szereg procesów gospodarczych o zasięgu międzynarodowym. Kupcy ci odegrali istotną rolę we włączeniu ziem polskich do dalekosiężnej wymiany z Flandrią, Holandią, ziemiami dzisiejszej Belgii, wschodnią Francją i Anglią. Proces ten stał się podstawą szybkiego rozwoju gospodarczego Królestwa Polskiego za panowania dwóch ostatnich Piastów, a zwłaszcza za Kazimierza Wielkiego. Gwałtowny rozwój handlu pomiędzy obszarami Morza Północnego i Bałtyckiego, a także rozkwit żeglugi przez Sund przyczyniły się w dalszej perspektywie do powstania dwóch stref gospodarczych w tej części Europy.

Ponieważ kolejność referowania zagadnień zmuszała do częstej zmiany wątku i ciągłego przeskakiwania z zagadnienia na zagadnienie, dla jasności przedstawionych ustaleń przyjrzyjmy się jeszcze raz referowanym w artykule wydarzeniom w porządku chronologiczno-rzeczowym.

Dzięki przypomnieniu rezultatów mało znanej pracy niemieckiego mediewisty Karla-Ottona Ahnsehla o handlu morskim i kupiectwie Torunia w II połowie XIV w. udało się wykazać, iż handel miedzią węgierską, którego szlak biegł przez 
ziemie polskie, odegrał znacznie większą rolę w dziejach średniowiecznej Europy Środkowej, niż dotychczas sądzono. Gdy pamiętamy o znaczeniu gospodarczym tego handlu, łatwiej zrozumieć szereg wydarzeń politycznych w okresie późnego średniowiecza, a zwłaszcza na przełomie XIII i XIV w. Pierwszym władcą na ziemiach polskich, który z całą pewnością rozumiał znaczenie tego handlu dla swojego władztwa i przywiązywał dużą wagę do jego rozwoju, był Wacław II. Zapewne przesadą byłoby stwierdzenie, że dążąc do opanowania Małopolski, miał on przed oczyma zyski płynące $\mathrm{z}$ tego handlu, ale to jednak on podjął związane $\mathrm{z}$ nim ważne decyzje ekonomiczne. Niemal pierwszymi posunięciami tego władcy w Małopolsce były mianowicie lokacja Nowego Sącza oraz przyznanie Podolińcowi prawa składu. Obydwie decyzje wiązały się z handlem miedzią; Nowy Sącz stał się dzięki temu ważnym ośrodkiem na miedzianym szlaku, gdzie rozładowywano wozy z miedzią spiską i dalej spławiano Dunajcem do Wisły z ominięciem Krakowa. Ustanowienie prawa składu w Podolińcu, położonym na trasie Koszyce-Kraków, faworyzowało małopolskich kupców w stosunku do kupców węgierskich i pruskich.

Drugim władcą, który zrozumiał wagę handlu miedzią, był Władysław Łokietek. Jeszcze przed przejęciem władzy na Pomorzu Gdańskim i w Wielkopolsce podjął ścisłą współpracę z lubeczanami, którzy penetrowali ten szlak od strony Gdańska. Początki ich zaangażowania się $\mathrm{w}$ ten handel są bardzo słabo oświetlone przez źródła. Początkowo lubeczanie w tej dziedzinie zapewne współpracowali z Gdańskiem. Świadectwem poprawnych stosunków pomiędzy Gdańskiem a Lubeką w tym czasie jest dokument z 13 III 1295 r., w którym sołtys i rajcy gdańscy oświadczają, iż w sprawach sądowych, rozpatrywanych we dworze kupieckim w Nowogrodzie Wielkim, apelować należy wyłącznie do Lubeki ${ }^{152}$. Oświadczenie takie złożyło wiele innych miast hanzeatyckich i z tego powodu nie należy wyciągać z niego zbyt daleko idących wniosków, ale można na tej podstawie przypuszczać, że stosunki pomiędzy Gdańskiem a Lubeką były wówczas poprawne. Lubeczanie, jeszcze w tym samym 1295 r., nawiązali ścisłą współpracę z księciem Władysławem Łokietkiem, władającym wówczas tylko ziemiami brzeską, łęczycką i sieradzką, przez które przebiegał szlak miedziany z Krakowa do Torunia. Współpraca pomiędzy Lubeką a Łokietkiem pogłębiła się, gdy książę ten objął we władanie Wielkopolskę i Pomorze Gdańskie. W 1298 r. lubeczanie wywalczyli na obszarze całego władztwa Władysława Łokietka szereg przywilejów handlowych, a w Gdańsku uzyskali niemal pozycję monopolistyczną, m.in. prawo wzniesienia eksterytorialnego kantoru do przechowywania towarów. Kantor ów, można sądzić, służył głównie do przechowywania miedzi i innych towarów spławianych Wisłą i transportowanych drogą lądową, m.in. przez księstwa pozostające pod władzą Łokietka. Wiadomo jednak, że lubeczanie trudnili się w tym czasie handlem miedzią węgierską i że transportowali ją do Flandrii. Można przypuszczać, że dzięki pomocy Władysława Łokietka stali się głównymi pośrednikami tego handlu pomiędzy ziemiami polskimi a Flandrią.

Błędy Władysława Łokietka w polityce wewnętrznej w Wielkopolsce przyczyniły się do upadku jego władzy w tej dzielnicy i niemal równocześnie w pozostałych jego księstwach. Znamienne, że Wacław II nie zadowolił się opanowaniem dziedzictwa

${ }^{152}$ PllUB nr 521, 536. 
Przemysła II wraz z Pomorzem Gdańskim, ale wygnał też Władysława Łokietka z jego księstw dziedzicznych, tj. z Kujaw oraz ziem łęczyckiej i sieradzkiej. Najnowsza literatura upadek władzy Łokietka w księstwach dziedzicznych tłumaczy m.in. zawarciem przez Władysława Łokietka kompromitującego porozumienia z wysłannikami króla czeskiego w Klęce 23 VIII 1299 r. ${ }^{153}$ Niewątpliwie tak było, ale zapewne nie bez wpływu pozostał fakt, że Wacław II - dzięki włączeniu do swojego władztwa dziedzicznych księstw Władysława Łokietka oraz Pomorza Gdańskiego - poddawał swojej kontroli cały szlak miedziany, od granicy z Węgrami aż po Gdańsk. Płynące stąd korzyści powodowały, że dawni poddani Łokietka nie byli skłonni za wszelką cenę popierać tego władcę. $Z$ drugiej strony okoliczności te skłaniały Wacława II do zajęcia bezkompromisowej postawy w walce o pozyskanie dziedzicznych księstw Władysława, przez które biegł ów ważny szlak handlowy, przynoszący ogromne zyski z opłat celnych. Tłumaczy to też może postępowanie Wacława II, który wcześniej, np. w przypadku księstw śląskich, wymuszał złożenie hołdu, ale nie pozbawiał dziedzictwa panujących tam książąt. Za Łokietkiem „nie płakali” też w 1300 r. gdańszczanie, upokorzeni wcześniej przez polskiego władcę, który przekazał wszelkie dochody z handlu miedzią w ręce lubeczan. Tym ostatnim nie sprzyjała jednak nowa sytuacja. Najpewniej jako bliscy sojusznicy Łokietka nie cieszyli się poparciem Wacława II. Można również przypuszczać, że Krzyżacy w czasie swoich krótkich rządów w Gdańsku, sprawowanych w imieniu Wacława, też nie wspierali lubeczan, na co wskazuje późniejsze ich wsparcie dla Westfalczyków. Największym zagrożeniem dla interesów lubeczan nad Wisłą były najpewniej ich wewnętrzne kłopoty i wojny z najbliższymi sąsiadami, a w końcu wymuszona „opieka” duńska. Nie wiemy tego na pewno, ale wiele wskazuje na to, że lubeczanie w czasie rządów czeskich całkowicie utracili swoją dawną pozycję w handlu miedzią jako pośrednika pomiędzy ziemiami polskimi a Flandrią. Ich miejsce zajęli kupcy westfalscy, głównie z Dortmundu i Soestu, którzy w momencie kryzysu władztwa Przemyślidów na ziemiach polskich w 1304 i 1305 r. osiedlili się w krzyżackim wówczas Toruniu, gdzie opanowali urzędy i przejęli pośrednictwo w handlu miedzią pomiędzy ziemiami polskimi a Flandrią.

Ważną rolę w odzyskaniu władzy przez Władysława Łokietka w latach 1304-1306 odegrał palatyn węgierski Amadej. W pewnym momencie udzielił on wygnanemu Władysławowi Łokietkowi schronienia w swoich dobrach, a następnie wsparł go militarnie i zapewne też finansowo, co umożliwiło księciu powrót do Polski w $1304 \mathrm{r}$. Amadej pragnął osłabić Wacława II, którego syn pretendował do korony węgierskiej, a przy okazji zaszkodzić interesom niechętnych sobie Koszyc. W ramach tej polityki Amadej zaaranżował też zapewne małżeństwo popieranego przez siebie króla węgierskiego Karola Roberta z Marią, córką Kazimierza bytomskiego, który był bratem ciotecznym Władysława Łokietka. Dzięki temu małżeństwu udało się „wyrwać” z obozu Przemyślidów Kazimierza, a najpewniej też i jego brata Bolesława opolskiego, wcześniej lenników Wacława II. Strategiczne położenie księstw górnośląskich,

${ }^{153}$ Kodeks dyplomatyczny Wielkopolski, t. II, nr 818; zob. T. J u r e k, Dyplomatyka i łowy. Za kulisami układu klęckiego (1299), w: Miasta, ludzie, instytucje, znaki, Kraków 209, s. 27-41; t e n ż e, Polska droga, s. 175 n. 
zwłaszcza bytomskiego, utrudniało Czechom komunikację z Krakowem i innymi posiadłościami polskimi. Małżeństwo to zawarte najpóźniej w 1306 r., a najpewniej już w poprzednim roku, wciągnęło do sojuszu z Węgrami obok Władysława Łokietka i Kazimierza bytomskiego także księcia halicko-włodzimierskiego Jerzego Lwowica, najpewniej wuja Marii bytomskiej.

Wsparcie Amadeja, a zwłaszcza fakt, że kontrolował on niemal całkowicie węgierski odcinek miedzianego szlaku handlowego, niezwykle wzmacniało pozycję Władysława Łokietka. Dla mieszczaństwa zaangażowanego w ten handel na ziemiach polskich nie było ostatecznie innego wyjścia, jak podporządkowanie się jego władzy. Kupcy zaangażowani w zyskowny handel miedzią zdawali sobie sprawę, że przy jakimkolwiek sprzeciwie Łokietek w każdej chwili może ściągnąć na nich gniew Amadeja, który już wcześniej znajdował wiele powodów, aby im uprzykrzać życie. Węgierska pomoc wpływała też na poparcie Łokietka przez możnych i rycerstwo. Nie podzielali tych uczuć Wielkopolanie, przez których ziemię nie przebiegał szlak miedziany. Znaczenie i udział kupców krakowskich w handlu miedzią oraz śmierć Wacława III przesądziły ostatecznie o podporządkowaniu się Krakowa i całej Małopolski Władysławowi Łokietkowi w 1306 r. Za cenę podporządkowania się kupcy krakowscy uzyskali w kilka dni po wiecu uznającym władzę Władysława Łokietka ważne koncesje, w sposób szczególny uprzywilejowujące ich w handlu miedzią. Przywilej ten był też zgodny z oczekiwaniami Amadeja, gdyż osłabiał kupców koszyckich i zmusił ich do uległości wobec palatyna. Utrzymanie przez Łokietka ziem, które opanował w latach 1304-1306, było niezwykle kosztowne. Znaczą część koniecznych środków książę pozyskiwał zapewne z opłat celnych. Jak donosi Jan Długosz, poważne sumy pieniędzy na prowadzenie wojen związanych z restytucją władzy Władysław Łokietek uzyskiwał przez nakładanie dodatkowych ceł i opłat na mieszczan krakowskich, którzy w jego państwie odgrywali główną rolę w handlu węgierską miedzią. Opłaty te były z pewnością niemałe, a wynikało to $\mathrm{z}$ dwóch faktów. Po pierwsze, potrzeby były ogromne, a po drugie, władca polski nie musiał się specjalnie liczyć ze zdaniem krakowian, którzy nie mogli sobie pozwolić na opór ze względu na strach przed represjami ze strony Amadeja. Sytuacja uległa całkowitej zmianie, gdy Amadej został zabity w czasie rozruchów w Koszycach 5 IX $1311 \mathrm{r}$. Gdy tylko mieszczanie małopolscy, uczestniczący w handlu z Węgrami, dowiedzieli się, że koszyczanie nie tylko nie zostali za ten czyn ukarani przez króla Karola Roberta, ale nawet wsparci przez niego, natychmiast zbuntowali się przeciwko Łokietkowi. Jako pierwsi wystąpili zapewne niektórzy sandomierzanie ze swoimi wójtami na czele, ale wydaje się, że ich bunt został dość szybko spacyfikowany. Nieco później, zapewne w listopadzie lub na początku grudnia 1311 r., doszło do wybuchu buntu mieszczan krakowskich pod wodzą wójta Alberta. Przez kilka miesięcy nie udało się buntownikom opanować zamku na Wawelu ani Władysławowi Łokietkowi spacyfikować miasta. Można przypuszczać, że wsparcie, jakiego udzielił buntownikom Bolesław opolski, przybywając do Krakowa ze swoimi wojskami pod koniec marca lub na początku kwietnia 1312 r., było spowodowane przez intrygę węgierską. Karol Robert, który przygotowywał się właśnie do walnej rozprawy ze stronnictwem synów Amadeja, musiał się poważnie obawiać, że Władysław Łokietek przyjdzie im z pomocą. W związku z tym prawdopodobna wydaje się hipoteza, 
że gdy poselstwo węgierskie zjawiło się na pogrzebie zmarłego 10 III 1312 r. Kazimierza bytomskiego, teścia króla węgierskiego, to wykorzystało ten moment, aby przekonać brata zmarłego, mianowicie księcia Bolesława opolskiego, do wsparcia buntu krakowian. Taki krok całkowicie uniemożliwiał księciu Władysławowi Łokietkowi przybycie z pomocą Amadejowicom, którzy starli się z siłami Karola Roberta i ponieśli klęskę w bitwie pod Rozgony 15 VI 1312 r. Niedobitki pokonanych schroniły się w Polsce, a Władysław Łokietek jeszcze w 1323 r., w kilka lat po tym, gdy jego córka Elżbieta poślubiła Karola Roberta, skutecznie prosił się o łaskę dla niektórych dawnych węgierskich buntowników. Można odrzucać hipotezę o węgierskiej inspiracji wystąpienia Bolesława opolskiego, ale w świetle wydarzeń w północnych Węgrzech w 1311 i 1312 r. trzeba całkowicie odrzucić przypuszczenia, jakoby za buntem wójta Alberta stał nowy król czeski Jan Luksemburski. Należy też odrzucić wszelkie poglądy, iż krakowianie zbuntowali się jako Niemcy niechętni polskiemu władcy. Nie był to bunt o charakterze narodowym czy etnicznym, chociaż niewątpliwie wśród polskich elit rycerskich wzbudził niechęć do Niemców.

\section{BIBLIOGRAFIA}

Ahnsehl K.-O., Thorns Seehandel und Kaufmannschaft um 1370, Marburg 1961.

Antonín R., Działalność polityczna Jana Luksemburskiego w okresie buntu krakowskiego wójta Alberta i jego ocena w czeskiej historiografii, w: Bunt wójta Alberta. Kraków i Opole we wzajemnych związkach w XIV w., Kraków 2013 (Annales Universitatis Paedagogicae Cracoviensis, Studia Historica 13).

Balzer O., Królestwo Polskie 1295-1370, t. I-III, Lwów 1919-1920 (wyd. 2: Kraków 2005).

Baszkiewicz J., Powstanie zjednoczonego państwa polskiego na przełomie XIII i XIV wieku, Warszawa 1954.

Bielińska M., Kancelaria Władysława Łokietka w latach 1296-1299. Ze studiów nad kancelarią wielkopolską, Studia Źródłoznawcze 6, 1961.

Bieniak J., Wielkopolska, Kujawy, ziemie łęczycka i sieradzka wobec problemu zjednoczenia państwowego w latach 1300-1306, Torun 1969.

Blanár D., Omodejovci - strojcovia bitky pri Rozhanovciach, w: Bitka pri Rozhanovciach v kontexte slovenských a uhorských dejín, Košice 2012.

Bobrzyński M., Bunt wójta krakowskiego Alberta z roku 1311, w: tegoż, Szkice i studia historyczne, t. I, Kraków 1922.

Budkowa Z., Rocznik miechowski, Studia Źródłoznawcze 5, 1961.

Bunt wójta Alberta. Kraków i Opole we wzajemnych związkach w XIV w., Kraków 2013 (Annales Universitatis Paedagogicae Cracoviensis, Studia Historica 13).

Czaja R., Strefa bałtycka w gospodarce europejskiej w XIII-XIV wieku ze szczególnym uwzględnieniem Prus krzyżackich, w: Ziemie polskie wobec Zachodu. Studia nad rozwojem średniowiecznej Europy, red. S. Gawlas, Warszawa 2006.

Czaja R., Udział wielkich miast pruskich w handlu hanzeatyckim, cz. 1-2, Zapiski Historyczne 60, 1995, z. 2-3 i 4.

Czaja R., Urzędnicy miejscy Torunia. Spisy, cz. I, Toruń 1999.

Dąbrowski J., Pochodzenie rodu Amadejów, Przegląd Polski 46, 1912.

Dąbrowski J., Z czasów Łokietka. Studia nad stosunkami polsko-węgierskimi w XIV w., cz. 1, Rozprawy Akademii Umiejętności, Wydział Historyczno-Filozoficzny 59, 1916.

Długokęcki W., Hanza a Gdańsk na przełomie XIII i XIV wieku, w: „Rzeź gdańska” z 1308 roku w świetle najnowszych badań, Gdańsk 2009.

Długopolski E., Bunt wójta Alberta, Rocznik Krakowski 7, 1905.

Długopolski E., Władysław Łokietek na tle swoich czasów, Wrocław 1951. 
Dollinger Ph., Dzieje Hanzy XII-XVII w., thum. V. Soczewińska, Warszawa 1997.

Dorna M., Bracia zakonu krzyżackiego w Prusach w latach 1228-1305. Studium prozopograficzne, Poznań 2004.

Drelicharz W., Annalistyka małopolska XIII-XV wieku. Kierunki rozwoju wielkich roczników kompilowanych, Kraków 2003.

Ehbrecht W., Skizzen und Überlegungen zur älteren Verfassungsgeschichte deutscher Städte, Köln-Weimar-Wien 2001.

Fahlbusch H., Eine Einführung in das Thema der Tagung, w: Wasserstraßen zwischen Elbe, Nord- und Ostsee einst und jetzt und weitere wasserhistorische Beiträge, Siegburg 2011 (Schriften der Deutschen Wasserhistorischen Gesellschaft 17).

Gawlas S., Möglichkeiten und Methoden herrschaftlicher Politik im östlichen Europa im 14. Jahrhundert, w: Die „Blüte” der Staaten des östlichen Europa im 14. Jahrhundert, Wiesbaden 2004.

Gawlas S., O kształt zjednoczonego Królestwa. Niemieckie władztwo terytorialne a geneza społeczno-ustrojowej odrębności Polski, Warszawa 1996.

Grabowska A., Bunt wójta Alberta w historiografii polskiej, w: Bunt wójta Alberta. Kraków i Opole we wzajemnych związkach w XIV w., Kraków 2013 (Annales Universitatis Paedagogicae Cracoviensis, Studia Historica 13).

Graßmann A., Lübeckische Geschichte, Lübeck 1989.

Halaga O., Boj Košic proti oligarchii Omodejovcov a Matúš Trenčiansky, Hitorický časopis 34, 1986, nr 3.

Halaga O., Kaufleute und Handelsgüter der Hanse im Karpatengebiet, Hansische Geschichtsblätter $85,1967$.

Halaga O., Košice - Balt. Výroba a obchod v styku východoslovenských miest s Pruskom (1275-1526), Košice 1975.

Halaga O., Počiatky Košíc a zrod metropoly, Košíce 1993.

Homza M., Rozwój stosunków osadniczo-etnicznych Spiszu we wczesnym średniowieczu, w: Historia Scepusii, t. I, Bratislava-Kraków 2010.

Isenmann E., Die deutsche Stadt im Mittelalter 1150-1550. Stadtgestalt, Recht, Verfasssung, Stadtregiment, Kirche, Gesellschaft, Wirtschaft, Köln-Weimar-Wien 2014.

Jan J., Václav II. Král na stř́brném trůnu 1283-1305, Praha 2015.

Jasiński K., Gdańsk pod rządami Władysława Łokietka i Wacławów czeskich, w: Historia Gdańska, t. I, Gdańsk 1978.

Jasiński K., Maria, w: Polski słownik biograficzny, t. XX (1975).

Jasiński K., Rodowód Piastów śląskich, wyd. 2, Kraków 2007.

Jasiński K., Z problematyki zjednoczenia państwa polskiego na przełomie XIII i XIV wieku, Zapiski Historyczne 21, 1956, z. 1-2.

Jasiński K., Zajęcie Pomorza Gdańskiego przez Krzyżaków w latach 1308-1309, Zapiski Historyczne 31, 1966.

Jasiński K., Zburzenie miasta Gdańska przez zakon krzyżacki w 1308 r., Zapiski Historyczne 41, 1976, z. 3.

Jasiński T., Początki Torunia na tle osadnictwa średniowiecznego, Zapiski Historyczne 46, 1981, z. 4.

Jasiński T., Rola Piastów mazowieckich w handlu hanzeatycko-ruskim na przełomie XIII/ XIV w., w: Dziedzictwo książąt mazowieckich, Warszawa 2017.

Jasiński T., Uwarunkowania lokacji Poznania, w: Civitas Posnaniensis. Studia z dziejów średniowiecznego Poznania, Poznań 2005.

Judziński J., Układy polsko-krzyżackie z 1309 roku w sprawie zwrotu Pomorza Gdańskiego, Komunikaty Mazursko-Warmińskie 1994, nr 2-3.

Jurek T., Dyplomatyka i łowy. Za kulisami układu klęckiego (1299), w: Miasta, ludzie, instytucje, znaki, Kraków 2009.

Jurek T., Dziedzic Królestwa Polskiego. Książę głogowski Henryk (1274-1309), wyd. 2, Kraków 2006. 
Jurek T., Jana Baszkiewicza Powstanie zjednoczonego państwa polskiego z perspektywy półwiecza, Czasopismo Prawno-Historyczne 57, 2005, z. 1.

Jurek T., Polska droga do korony królewskiej 1295-1300-1320, w: Proměna středovýchodní Evropy raného a vrcholného středověku. Mocenské souvislosti a paralely, Brno 2010.

Kętrzyński W., O rocznikach polskich, Rozprawy Akademii Umiejętności, Wydział Historyczno-Filozoficzny 34, 1896.

Kießelbach A., Die wirtschaftlichen Grundlagen der deutschen Hanse und die Handelsstellung Hamburg, Berlin 1907.

Kłodziński A., Jeden czy dwa bunty wójta Alberta?, w: Studia historyczne ku czci Stanisława Kutrzeby, t. II, Kraków 1938.

Kłodziński A., Z dziejów pierwszego krakowskiego buntu wójta Alberta, Zapiski Towarzystwa Naukowego w Toruniu 14, 1948, z. 1.

Koczy L., Materiały do dziejów handlu hanzy pruskiej z zachodem, Rocznik Gdański 7/8, 1933/1934.

Kristó Gy., Die Macht der Territorialherren in Ungarn am Anfang des 14. Jahrhunderts, w: Etudes historiques hongroises 1985 publiées a l'occasion du XVI ${ }^{\mathrm{e}}$ Congres International des Sciences Historiques, t. I, Budapest 1985.

Kristó Gy., A rozgonyi csata, Budapest 1978.

Kristó Gy., Károly Róbert családja, Aetas 20, 2005.

Kristó Gy., Károly Róbert elsö felesé, Acta Universitatis Szegediensis de Attila József nominatae, Acta Historica 86, 1988.

Kutrzeba S., Handel Krakowa w wiekach średnich, Kraków 1902 (przedruk w tegoż, Finanse i handel średniowiecznego Krakowa, Kraków 2009).

Labuda G., Uwagi o zjednoczeniu państwa polskiego na przełomie XIII i XIV wieku, Kwartalnik Historyczny 62, 1955, nr 3.

Labuda G., Walka o Pomorze Gdańskie na przełomie XIII i XIV wieku, w: Historia Pomorza, t. I, cz. 1, Poznań 1969.

Lesiński H., Początki i rozwój stosunków polsko-hanzeatyckich w XIII w., Przegląd Zachodni 8, 1952, nr 5/6.

Luntowski G., Kleine Geschichte des Rates der Stadt Dortmund, Dortmund 1970.

Luntowski G., Högel G., Schilp T., Reimann N., Geschichte, der Stadt Dortmund, Dortmund 1994. Maráz K., Václav III. (1289-1306). Poslední Přemyslovec na českém trůné, České Budějovice 2007.

Mentzel-Reuters A., Arma spiritualia. Bibliotheken, Bücher und Bildung im Deutschen Orden, Wiesbaden 2003 (Beiträge zum Buch- und Bibliothekswesen 47).

Niwiński M., Wójtostwo krakowskie w wiekach średnich, Kraków 1938.

Nowacki B., Czeskie roszczenia do korony w Polsce w latach 1290-1335, Poznań 1987.

Nowakowski T., Małopolska elita władzy wobec rywalizacji o tron krakowski w latach 12881306, Bydgoszcz 1992.

Obara-Pawłowska A., Polish and Hungarian relations in the Middle Ages (from the second half of the $13^{\text {th }}$ century to the end of the $14^{\text {th }}$ century), w: Hungaro-Polonica. Young Scholars on Medieval Polish-Hungarian Relations, Pécs 2016.

Obara-Pawłowska A., Polityka gospodarcza Władysława Łokietka, Lublin 2014.

Paszkiewicz B., Mennictwo Władysława Łokietka, Wiadomość Numizmatyczne 30, 1986, z. 1-2 (115-116).

Pęckowski Z., Miechów. Studia z dziejów miasta i Ziemi Miechowskiej do roku 1914, Kraków 1967.

Pietras T., „Krwawy wilk z pastorałem”. Biskup krakowski Jan zwany Muskatą, Warszawa 2001.

Reetz J., Bistum und Stadt Lübeck um 1300. Die Streitigkeiten und Prozesse unter Burkhard von Serkem, Bischof 1276 bis 1317, Lübeck 1955.

Reetz J., Nachträge zu den Streitigkeiten zwischen Bistum und Stadt Lübeck um 1300, Zeitschrift des Vereins für Lübeckische Geschichte 45, 1965.

Renken F., Der Handel der Königsberger Grossschäfferei des Deutschen Ordens mit Flander um 1400, Weimar 1937. 
Rozenkranz E., Dzieje kantoru hanzeatyckiego w Gdańsku, Studia i Materiały do Dziejów Wielkopolski i Pomorza 13, 1978, z. 1 (25).

Samsonowicz H., Die Hanse an der unteren Weichsel im 13. Jahrhundert, Hansiche Geschichtsblätter 106, 1988.

Samsonowicz H., Lubeczanie a ziemie Polski w XIII w., Acta Universitatis Nicolai Copernici 204, Historia 24, Torun 1990.

Samsonowicz H., Miasta wobec zjednoczenia Polski w XIII/XIV wieku, w: Ars historica. Prace z dziejów powszechnych i Polski, Poznań 1976.

Semkowicz W., O pochodzeniu i rozsiedleniu rodu Amadejów w Polsce, Miesięcznik Heraldyczny 5, 1912, nr 9-10.

Semrau A., Katalog der Geschlechter der Schöffenbank und des Ratsstuhls in der Altstadt Thorn 1233-1602, Mitteilungen des Coppernicus-Vereins für Wissenschaft und Kunst zu Thorn 46, 1938.

Słownik historyczno-geograficzny województwa krakowskiego w średniowieczu, cz. I-V, Wrocław 1980 - Kraków 2016.

Spěváček J., Jan Lucemburský a jeho doba 1296-1346, Praha 1994.

Sroka S. A., A Hungarian-Galician mariage at the beginning of the fourteenth century?, Harvard Ukrainian Studies 16, 1994.

Sroka S. A., Genealogia Andegawenów węgierskich, Kraków 1999.

Sroka S. A., Ki volt Károly Róbert elsö felesége?, Aetas 1, 1994.

Sroka S. A., Kontakty Władysława Łokietka z Węgrami w świetle nowych dokumentów, Studia Historyczne 38, 1995.

Sroka S. A., Piastówna śląska Maria, królową Węgier, w: tegoż, Z dziejów stosunków polsko-węgierskich w późnym średniowieczu. Szkice, Kraków 1995.

Sroka S. A., Wokół mariażu Karola Roberta z Piastówną śląską Marią. Biuletyn Polskiego Towarzystwa Heraldycznego 11, 1994.

Sroka S. А., Чи існувала руська дружина угорського короля Карла Роберта на початку XIV століття?, Княжа доба 3, 2010.

Šusta J., Král cizinec (České dějiny, t. II, cz. 2), Praha 1939.

Šusta J., Počátky lucemburské 1308-1320 (Dvě knihy českých dějin II), wyd. 2, Praha 1926.

Šusta J., Poslední Přemyslovci a jejich dědictví 1300-1308 (Dvě knihy českých dějin I), wyd. 2, Praha 1926.

Šusta J., Soumrak Přemyslovců a jejich dědictví (České dějiny, t. II/1), Praha 1935.

Śliwiński B., Data zburzenia Gdańska przez Zakon Krzyżacki, Kwartalnik Historyczny 96, 1990, nr 3-4.

Śliwiński B., Pomorze Wschodnie w okresie rządów księcia polskiego Władysława Łokietka w latach 1306-1309, Gdańsk 2003.

Śliwiński B., Rzeź i zniszczenie Gdańska przez Krzyżaków w 1308 roku, Gdańsk 2006.

Śliwiński B., Wydarzenia w Gdańsku i w okolicach w okresie od września do 12/13 listopada 1308 roku, w: „Rzeź gdańska” z 1308 roku w świetle najnowszych badań, Gdańsk 2009.

Trawkowski S., W sprawie powstania zjednoczonego państwa polskiego w XIII i XIV wieku: w związku z książką Jana Baszkiewicza, Powstanie zjednoczonego państwa polskiego na przełomie XIII i XIV wieku, Warszawa 1954, Przegląd Historyczny 47, 1956.

Uličný F., Vývoj politických vzt’ahov v Uhorskom královstve, najmä na východnom Slovensku, v prvej polovici 14. storočia, w: Bitka pri Rozhanovciach v kontexte slovenských a uhorských dejín, Košice 2012.

Vogel W., Geschichte der deutschen Seeschifffahrt, t. I, Berlin 1915.

Wyrozumski J., Dzieje Krakowa, t. I, Kraków 1992.

Ziegler U., Die Hanse: Aufstieg, Blütezeit und Niedergang der ersten europäischen Wirtschaftsgemeinschaft. Eine Kulturgeschichte von Handel und Wandel zwischen 13. und 17. Jahrhundert, Bern-München-Wien-Scherz 1996.

Zielińska-Melkowska K., Zagadnienie proweniencji elit mieszczańskich w ziemiach: chełmińskiej, lubawskiej i michałowskiej w XIII i XIV wieku, w: Genealogia. Rola związków 
rodzinnych i rodowych w życiu publicznym w Polsce średniowiecznej na tle porównawczym, Toruń 1996.

Ziemie polskie wobec Zachodu. Studia nad rozwojem średniowiecznej Europy, red. S. Gawlas, Warszawa 2006.

Zsoldos A., Kassa túzsai (Pillanatfelvétel 1311-ből Aba Amadé famíliájáról), Történelmi Szemle 39, 1997, nr 3-4.

Zsoldos A., King and oligarchs in Hungary at the turn of the thirteenth and fourteenth centuries, Hungarian Historical Review 2, 2013, nr 2.

Žemlička J., Do tř́ korun. Poslední rozmach Přemyslovců (1278-1301), Praha 2017.

\title{
Hungarian copper trade and the restitution of Ladislaus the Short's rule in Poland (1304-1312)
}

\author{
Summary
}

Hungarian copper trade played a major role in the political and social events in Poland at the beginning of the $15^{\text {th }}$ century. The return of Ladislaus the Short to Poland in 1304 and his subduing of Little Poland, the lands of Sieradz and Łęczyca, Kuiavia and Gdańsk Pomerania are easier to understand if one realises the international importance of that trade. The decisive role in Ladislaus the Short's regaining of power was played by the Hungarian palatine Amadej, under whose control the Hungarian segment of the copper route remained. He gave shelter to Ladislaus the Short and then supported him with military and financial aid, which made it possible for the duke to return to Poland in 1304. That expedition had two aims in the plans of Amadej: first, its intention was to weaken the Czech king Venceslaus II and his son (later king Venceslaus III), one of the pretenders to the Hungarian crown. Second, Amadej expected that taking Cracow, one of the most important trade centres on the copper route, by Ladislaus the Short would weaken the merchants of Košice, who were strong adversaries of Amadej and eagerly supported the Premislid rule in Hungary. The support from Amadej, and especially the fact that he had almost absolute control of the Hungarian segment of the copper trade route, greatly improved the position of Ladislaus the Short in his struggle for Polish lands. For the burghers involved in that trade on Polish lands there was eventually no other way than to submit to the rule of the Piast duke. The merchants realised that in case of any resistance, Ladislaus could easily direct Amadej anger against them, especially as he had already had many reasons for making their lives harder. To the nobles and knights Ladislaus appeared as a pretender both strong with Hungarian military support and financially credible. Sustaining the lands which he subdued in 1304-1306 was very expensive. The duke obtained large financial means by imposing taxes and dues on the burghers of Cracow, who could not oppose in fear of Amadej's repressions. Only when the latter was killed during the riots in Košice on 5 Septembber 1311, the Cracow merchants rebelled against Ladislaus. They were supported by Bolko of Opole, who in turn was urged to do that by the Hungarian king Charles Robert of Anjou. The contact between the Hungarian representatives and Bolko most probably took place during the funeral of Kazimierz of Bytom (who died on 10 March 1312), the brother of Bolko and father-in-law of the king of Hungary. Charles Robert was then in conflict with Amadej's family and was interested in retaining Ladislaus the Short in Little Poland. The main participants in copper trade were Westphalian merchants from Dortmund and Soest, who settled down in Toruń in 1305. This initiated a number of economic processes on international scale. Those merchants played an important role in incorporating Polish lands to the far reaching exchange with Flanders, Holland, the area of modern Belgium, eastern France and England. That process became the basis for intensive economic development of the Kingdom of Poland under the last two Piasts, especially Casimir the Great. 